\title{
The Optimal Precision of Administrative Rules
}

\author{
Colin S. Diver†
}

A state judge enjoins a liquor licensing board from denying future license applications until it adopts written rules to flesh out a vague "public interest" standard. ${ }^{1}$ A federal court orders the Federal Communications Commission to entertain requests for waivers from its "clear channel" rules, noting that "a system where regulations are maintained inflexibly without any procedure for waiver poses legal difficulties."2 A congressional committee studying federal bank chartering by the Comptroller of the Currency assails the Comptroller's "reliance on vague standards [which accord him] unbridled discretion in the chartering process." Meanwhile, two political scientists lament the increasing "imposition of uniform regulatory requirements in situations where they do not make sense."

The common thread that connects these dissimilar complaints is dissatisfaction with the precision of administrative rules, because of either administrative underprecision or excessive regulatory rigidity. ${ }^{\mathrm{s}}$

This Article attempts to bring into sharper focus the assumptions and concerns about regulatory precision implicit in these diverse opinions about administrative policymaking. Those who take it upon themselves, by choice or obligation, to judge the quality of administrative rules must

$\dagger$ Professor of Law, Boston University.

This Article is based in part on a report prepared by the author for the Administrative Conference of the United States. The author acknowledges with gratitude the assistance of the members and the staff of the Conference. Portions of the Article are part of a larger study of administrative policymalsing supported by a grant from the Russell Sage Foundation. The author is, however, solely responsible for the contents of this Article.

1. Sun Ray Drive-In Dairy, Inc. v. Oregon Liquor Control Comm'n, 16 Or. App. 63, 517 P.2d 289 (1973); see also Megdal v. Oregon State Bd. of Dental Examiners, 288 Or. 293, 320-21, 605 P.2d 273 (1980) (Board of Dental Examiners had no grounds to revoke dentist's license because "unprofessional conduct" was not defined in statute and no rule forbade conduct).

2. WAIT Radio v. FCG, 418 F.2d 1153, 1157 (D.C. Cir. 1969).

3. Majority Staff of Senate Comm. on Banking, Housing \& Urban Affairs, 96th Cong., 2d Sess., Majority Staff Study on Chartering of National Banks 4 (Comm. Print 1980) [hereinafter cited as Majority STAFF StUdy].

4. E. Bardach \& R. Kagan, Gotng By the Book: The Problem of Regulatory UnreaSONABLENESS 58 (1982).

5. Throughout this Article, I use the term "rule" broadly, to refer to the linguistic formula used by an administrative agency to express its governing policy. The term should not be confused with the much narrower meaning assigned to it by the Administrative Procedure Act $\S 2$ (c), 5 U.S.C. § 551(4) (1976). 
determine the degree of formal precision to demand from their authors. They need, to paraphase Judge Skelly Wright, a "standard for standards." The purpose of this Article is to fashion such a "standard for standards" and to illustrate its applications and limitations.

The Article begins by defining the concept of rule "precision." Using an example based on the FAA's mandatory retirement rule, I distinguish three elements of regulatory precision_- "transparency," "accessibility," and "congruence"- and explore the relationships among them. In Section II, I develop criteria to determine the appropriate degree of regulatory precision. I apply this analytical framework in Section III to the evaluation of four very different administrative policies: the FAA's retirement rule, the Comptroller of the Currency's standards for chartering national banks, the Social Security Administration's grid rule for determining disability, and the Immigration Service's criteria for granting permanent resident status for nonimmigrant aliens.

Section IV explores the model's applicability to administrative policymaking. This section discusses the two kinds of "administrative failure"-imperfect information and the divergence of social and private preferences-that seem most likely to cause poorly drafted regulations. The Article concludes by drawing lessons from this model for reviewing courts faced with challenges to the precision of administrative rules.

\section{The Concept of Rule Precision}

One would naturally expect the concept of rule precision to occupy a central place in any coherent philosophy of law. Yet legal philosophers differ considerably in both the relative significance they attach to formal rules and the attributes of rules with which they are most concerned. Gommentators have identified a wide variety of parameters to describe legal rules: generality and clarity, ${ }^{7}$ comprehensibility, ${ }^{8}$ accuracy of prediction, ${ }^{9}$ determinacy, ${ }^{10}$ weight, ${ }^{11}$ value, ${ }^{12}$ and consistency with social purpose. ${ }^{13}$ Before we can begin to make useful prescriptions about the precision of administrative rules, we must give the concept some added precision of its own.

6. Wright, Bejond Discretionary Justice (Book Review), 81 YALE L.J. 575, 587 (1972) (reviewing K. Davis, Discretionary Justice (1969)) ("We need, in short, some standards for when we should require standards.").

7. L. Fuller, The MoRality of LAw 46-49, 63-65 (1964).

8. H.L.A. HART, The ConCEPT OF LAW 121 (1961).

9. J. Frank, LAW AND THE MOdeRn Mind 118-19 (1930).

10. R. Dworkin, Taking Rights Seriously 24-26 (1977).

11. Id. at 26-28; Raz, Legal Principles and the Limits of Law, 81 YALE L.J. 823, 832-33 (1972).

12. See, e.g., R. Posner, Economic Analysis of Law 419-21 (2d ed. 1977); Landes \& Posner, Legal Precedent: A Theoretical and Empirical Analysis, 19 J. L. \& ECON. 249, 263-64 (1976).

13. See Friedman, Legal Rules and the Process of Social Change, 19 Stan. L. Rev. 786, 822-24 (1967). 


\section{A. Three Dimensions of Rules}

The success of a rule in effecting its purpose largely depends on the words a draftsman uses to express his intentions. ${ }^{14}$ A rational rulemaker will therefore be attentive to the probable effect of his choice of words upon the rule's intended audience. First, he will want to use words with well-defined and universally accepted meanings within the relevant community. I refer to this quality as "transparency."16 Second, the rulemaker will want his rule to be "accessible" to its intended audience-that is, applicable to concrete situations without excessive difficulty or effort. ${ }^{16} \mathrm{Fi}-$ nally, of course, a policymaker will care about whether the substantive content of the message communicated in his words produces the desired behavior. ${ }^{17}$ The rule should, in other words, be "congruent" with the underlying policy objective. ${ }^{18}$

One can see each of these objectives at work in contemporary debates about the precision of legal rules. Transparency is the virtue chiefly celebrated in the "void-for-vagueness" doctrine, ${ }^{10}$ as well as in judicial and scholarly attacks on unconfined legislative delegation ${ }^{20}$ and administrative

14. Implicit in this assertion is a rejection of the "nihilist" view that legal texts have any meaning that the reader chooses to assign to them. See Levinson, Law as Literature, 60 TEx. L. REv. 373, 373-77 (1982); Fish, Interpretation and the Pluralist Vision, 60 TEx. L. REv. 495, 503 (1982). I assume, at a minimum, that the addressees of most administrative rules are a "community" whose shared experiences or values can give objective (if not wholly deterministic) meaning to such texts. See P. Berger \& T. Luckmann, The Social Construction of Reality: A Treatise in the SociOLOGY OF KNOWLEDGE 34-46 (1966); White, Law as Language: Reading Law and Reading Literature, 60 TEX. L. REv. 415, 415-16 (1982).

15. Jerry Mashaw uses the term "transparency" to describe a similar idea. Mashaw, Administrative Due Process: The Quest for a Dignitary Theory, 61 B.U.L. REv. 885, 901 (1981). It is presumably this same notion that Hart has in mind when speaking of rules "which multitudes of individuals could understand," H.L.A. HART, supra note 8, at 121, that Fuller has in mind when speaking of a rule's "clarity," L. FulLER, supra note 7, at 63-65, and that Kennedy describes as "formal realizability," Kennedy, Form and Substance in Private Law Adjudication, 89 HaRv. L. REv. 1685, 1687-88 (1976).

16. See G. Tullock, Trials on Trial: A Pure Theory of Legal Procedure 180 (1980); Brodley, In Defense of Presumptive Rules: An Approach to Legal Rulemaking for Conglomerate Mergers, in The Conglomerate Corporation: An Anttroust Law and Economics SympoSIUM 249, 255-60 (1981).

17. For a graphic representation of this point, see Tussman \& tenBroek, The Equal Protection of the Laus, 37 CALIF. L. REv. 341, 346-49 (1949) (discussing passage of a hypothetical law for sterilization of suspected hereditary criminals); see also Cabell v. Chavez-Salido, 454 U.S. 432,440 (1982) (defining "specificity" of a classification as its degree of "over or underinclusive[ness]" in serving legitimate political ends).

18. I use the term "congruent" in a sense similar to that used by Paul Brest. P. BREsr, Processes of Constitutional Decisionmaking: Cases and Materials 478, 480 (1975); $c f$. L. Fuller, supra note 7, at 81 (using "congruence" to refer to the fit between the law as written and the law as applied).

19. See generally Note, The Void-for-Vagueness Doctrine in the Supreme Court, 109 U. PA. L. REv. 67 (1960) (examining cases where void-for-vagueness doctrine was invoked).

20. 'See Schechter Poultry Corp. v. United States, 295 U.S. 495, 551 (1935) (Cardozo, J., concurring). 
discretion. ${ }^{21}$ The asserted defect of an academic "misconduct" standard, for instance, was its failure to provide a sufficiently clear guide for students' behavior. ${ }^{22}$ The desire to make legal rules more accessible motivates recurrent calls for "simplification" of convoluted regimes like the tax code. $^{23}$ This urge also animates proposals to expand the use of per se rules to resolve complex issues of antitrust law. ${ }^{24}$ On the other hand, the concern primarily evoked by "irrebuttable presumption"25 and "required waiver"28 claims is congruence. A rule that makes eligibility for disability insurance turn on one's birth date, the argument runs, fails adequately to discriminate between those who are capable and those who are incapable of supporting themselves. ${ }^{27}$ Since any criterion for evaluating the "precision" of administrative rules should include these three values, it would be tempting simply to define as "precise" a rule that combined the virtues of transparency, accessibility, and congruence. But two formidable obstacles lie in the path of such a venture-measurement and tradeoffs.

\section{B. The Problem of Measurement}

We must ask initially how to translate the goals of transparency, accessibility, and congruence into usable criteria for evaluating specific rules. To sketch the dimensions of that task, I offer a simple illustration. ${ }^{28} \mathrm{Im}$ -

21. See K. Davis, Discretionary Justice: A Prelminary Inquiry 52-96 (1969).

22. Soglin v. Kauffman, 418 F.2d 163, 168 (7th Cir. 1969).

23. See, e.g., Bittker, Tax Reform and Tax Simplification, 29 U. Miami L. Rev. 1, 5-7 (1974); Brannon, Simplification and Other Tax Objectives, in Federal Income Tax Simplification 191 (C. Gustafson ed. 1979); Woodworth, Tax Simplification and the Tax Reform Act of 1969, 34 LAW \& Contemp. Prors. 711, 711, 713 (1969).

24. See Posner, The Next Step in the Antitrust Treatment of Restricted Distribution: Per Se Lpgality, 48 U. CHI. L. REv. 6, 23 (1981) (arguing for per se legality of vertical restraints in distribution absent inter-retailer cartels).

25. See generally Note, The Irrebuttable Presumption Doctrine in the Supreme Court, 87 Harv. L. REV. 1534 (1974) (examining constitutional underpinnings of irrebuttable presumption doctrine).

26. The required waiver cases examine the extent to which agencies may use bright-line rules to close off an individual's right to a hearing. See Aman, Administrative Equity: An Analysis of Exceptions to Administratize Rules, 1982 DuKE L.J. 277. Early decisions upheld the practice, but implied that agencies had to afford adversely affected persons an opportunity to seek a waiver from their terms. Although the Supreme Court has refused to read that implication as a universal requirement, FPC v. Texaco, Inc., 377 U.S. 33, 40-41 (1964); United States v. Storer Broadcasting Co., 351 U.S. 192, 205 (1956); National Broadcasting Co. v. United States, 319 U.S. 190, 224-25 (1943), the struggle to accommodate individual justice with mechanical rules continues, see, e.g., Matlovich v. Secretary of Air Force, 591 F.2d 852, 857 (D.C. Cir. 1978) (requiring greater flexibility in Air Force disciplinary rules); National Petroleum Refiners Ass'n v. FTC, 482 F.2d 672, 689-91 (D.C. Cir. 1973) (requiring greater flexibility in FTC trade regulations), cert. denied, 415 U.S. 951 (1974); WAIT Radio v. FCC, 418 F.2d 1153, 1157-59 (D.C. Cir. 1969) (requiring greater flexibility in FCC clear channel rules).

27. See Broz v. Schweiker, 677 F.2d 1351, 1360 (11th Cir. 1982) (absence of scientific support for age-based regulations supports case-by-case determination of physical ability to do job).

28. The illustration is drawn from the "age-60" pilot retirement rule, 24 Fed. Reg. 9776 (1959), upheld, Airline Pilots Ass'n, Int'l v. Quesada, 276 F.2d 892, 898 (2d Cir. 1960). The current rule is virtually identical to the original: "No person may serve as a pilot on an airplane engaged in [commercial] operations . . . if that person has reached his 60th birthday." 14 C.F.R. $\S 121.383$ (c) (1982). 
agine a policymaker who must establish certification criteria for commercial aircraft pilots. One aspect of that task is to define the circumstances under which a pilot, once certified, should no longer be eligible to serve in that capacity. Let us suppose our lawmaker has a rough idea of a policy objective: pilots should retire when the social cost of allowing them to continue, measured as the risk of accidents that they might cause multiplied by their consequences, exceeds the social benefit, measured as the costs avoided by not having to find and train a replacement. But how can the lawmaker capture this idea in a legal standard?

Let us initially offer three alternative verbal formulations for such a rule:

Model I: No person may pilot a commercial airplane after his sixtieth birthday.

Model II: No person may pilot a commercial airplane if he poses an unreasonable risk of an accident.

Model III: No person may pilot a commercial airplane if he falls within one of the following categories. (There follow tables displaying all combinations of values for numerous variables, including years and level of experience, hours of air time logged, age, height, weight, blood pressure, heart rate, eyesight, and other vital signs, that would disqualify a pilot from further eligibility to pilot aircraft.) $)^{29}$

Which formulation is most transparent? The answer is easy: Model I. Everyone knows exactly what the words "sixtieth" and "birthday" mean. The crucial concept of Model II-"unreasonable" risk-seems, by contrast, susceptible to widely varying interpretations. Suppose, however, that among the rule's intended audience, the term "unreasonable risk of accident" had acquired a very special meaning: namely, "older than $60 . "$ In that case, the two rules would be equally transparent. That contingency, however implausible here, nonetheless reminds us of the danger of judging a rule's transparency without looking beyond its words to its actual' impact.

The danger inherent in facial evaluation is even more evident in applying the other two criteria. Is the rule of Model II or Model III more accessible? The former is shorter and more memorable. It also apparently requires only a single judgment-the "reasonableness" of the risk. That

29. For a review of some possible parameters, see NAT'L INST. ON AgING, DeP'T of Health and Human Serv,, Report of the National Institute on aging Panel on the ExperIENCEd PILOT STUdy (August 1981) [hereinafter cited as NIA REPORT]. For promulgated illustrations of such tables, see 20 C.F.R. subpt. P, app. 2 (1982) (Social Security Adminsitration grid rule for determining disability); 28 C.F.R. $§ 2.20$ (1982) (U.S. Parole Commission parole release guidelines). 
judgment, however, may well rest on a set of subsidiary inquiries as numerous and complex as those encompassed within Model III's more explicit set of tables.

Similarly, our intuition that Model II is more congruent than, say, Model I, may be unreliable. The facial resemblance between Model II and the rulemaker's ultimate objective depends on the unverifiable assumption that "unreasonable" connotes "economically inefficient."

It might be possible to assess these alternatives by reducing our three values to some empirically measurable form. We could, for example, conduct an experiment in which we present a series of hypothetical questions to a random sample of a rule's intended audience and require them to apply it to specific situations. ${ }^{30}$ We might measure the rule's congruence by the ratio of agreement between the respondents' answers and the rulemaker's desired answers. We could use the ratio of internal agreement among respondents to measure the rule's transparency. Finally, we could construct an index of the rule's accessibility by assessing the average time (or money, in a more realistic experiment) that respondents invest in arriving at their answers. These measures, however, are at best only expensive proxies for the values that underlie them.

\section{The Problem of Tradeoffs}

Assuming that we could make reliable measurements along each of the three dimensions, we would still have to find a way to aggregate them in an overall evaluation. If transparency always correlated closely with accessibility and congruence, this would present no difficulty. Our three models of a pilot retirement rule, however, suggest that it does not. Each formulation has something to recommend it, but each also presents obvious difficulties. Model I may indeed be amenable to mechanical application, but it will undoubtedly ground many pilots who should continue flying and may allow some to continue who should be grounded. Even if we concede that Model II is simple and faithful to' our policymaker's intentions, it generates widely varying interpretations in individual cases. Model III is commendably objective and may even discriminate accurately between low and high risks. But it achieves this latter objective only at the cost of difficulty in application.

Attempting to escape from these tradeoffs with a fourth option seems hopeless. Suppose we begin with Model I's "age 60" version. Since this rule's greatest flaw is its apparent incongruity, we might try to soften its

30. For a discussion of intelligibility, see Ross, On Legalities and Linguistics: Plain Language Legislation, 30 Buffalo L. Rev. 317, 334-35 (1981). 
hard edges by allowing exceptions in particularly deserving cases. ${ }^{31}$ We could, for example, permit especially robust sexagenarians to continue flying. But this strategem merely poses a new riddle: how should we define the category of exempt pilots? There are, of course, many choices, but all of them seem to suffer in one degree or another from problems of opacity (e.g., "reasonably healthy"), incongruence (e.g., "able to press 150 pounds and run five miles in 40 minutes"), or inaccessibility (Model III's tables).

Similarly, starting from Model II's "unreasonable risk" standard, we could increase its transparency by appending a list of the components of "unreasonable risk"-for example, "taking into consideration the person's age, physical condition, mental alertness, skill and experience." Yet such laundry lists add relatively little transparency when both the meaning and relative weights of the enumerated terms remain unspecified. Providing the necessary specification, however, makes the standard less congruent or accessible.

\section{The Optimal Degree of Regulatory Precision}

The observation that various verbal formulations are likely to involve differing mixes of transparency, accessibility, and congruence offers little solace to a regulatory draftsman. Tradeoffs may be inevitable, but not all tradeoffs are equally acceptable. What our rulemaker needs is a normative principle for comparing formulations.

Invocation of moral values like fairness, equity, or community offers little promise. Each dimension of regulatory precision implicates important moral principles. Transparent rules help to assure equality by defining when people are "similarly situated"32 and divorcing the outcome of an official determination from the decisionmakers. An accessible rule, by contrast, promotes communal and "dignitary" values by enabling members of its audience to participate in its application to their individual circumstances. ${ }^{33}$ Congruence directly fosters the law's substantive moral aims by promoting outcomes in individual cases consistent with those aims.

These principles frequently work at cross-purposes, however, precisely

31. For a detailed account of the difficulties inherent in administering an exceptions policy, see Schuck, When the Exception Becomes the Rule: Regulatory Equity, the Exceptions Process, and the Formulation of Energy Policy (Feb. 16, 1983) (Discussion Draft Report to the Admin. Conf. of the U.S.) (exceptions to federal petroleum price and allocation rules).

32. But see Westen, The Emply Idea of Equality, 95 Harv. L. Rev. 537, 543-48 (1982) (equal treatment of equals constitutes a tautology).

33. See Tribe, Perspectives on Bakke: Equal Protection, Procedural Fairness, or Siructural Justice?, 92 Harv. L. Rev. 864, 869-70 (1979); Tribe, Structural Due Process, 10 Harv. C.R.-C.L. L. REv. 269, 283-88, 295-98 (1975) [hereinafter cited as Tribe, Structural Due Process]. On "dignitary" values, see Mashaw, supra note 15; Saphire, Specifying Due Process Values: Toward a More Responsite Approach to Procedural Protection, 127 U. PA. L. REv. 111, 117-25 (1978). 
because tradeoffs occur along the three dimensions of precision. A perfectly transparent rule ("no person with a surname ending in a vowel may be a pilot") may assure similar treatment of categorically similar cases, but it may also fail to provide defensible applications. A morally congruent rule ("immorality is prohibited") can be too vague to satisfy the moral imperatives of fair warning and meaningful participation. A perfectly transparent and congruent rule may be so cumbersome as to deprive its audience of fair warning.

\section{A. An Efficiency Criterion for Rule Precision}

Since tradeoffs among values are unavoidable, the morally sensitive rulemaker must reduce those conflicting values to some common denominator. One candidate is the currency of welfare economics-"social utility." ${ }^{\text {s4 }}$ A social utility-maximizing rulemaker would, for any conceivable set of rule formulations, identify and estimate the social costs and benefits flowing from each, and select the one with the greatest net social benefit. Subject to a constraint on his rulemaking budget or authority, the rulemaker would continue adding to his stock of rules so long as the marginal social benefit of the last increment exceeded its marginal cost. ${ }^{35}$

We can use our pilot retirement rule to sketch the dimensions of this task. Suppose our hypothetical policymaker wants to decide whether Model I or Model II is socially preferable. Several considerations argue in favor of Model I. It may, for example, produce a higher level of voluntary compliance, since the rulemaker can more readily charge pilots with its enforcement. For this reason, pilots are less likely to evade or sabotage the rule.

Model I also seems cheaper to enforce. Since it increases accuracy of prediction, there will be fewer requests for interpretation. Since it increases the level of compliance, there will be fewer violations to process. And since it is highly objective, the enforcement agency can quickly and accurately resolve the disputes that do arise. Model II, by contrast, will generate numerous and expensive conflicts. In the absence of clear standards, factfinding and offers of proof will range far and wide. The rule's audience will expend effort in interpreting the meaning of the standard and in making successive elaborations of its meaning in individual cases.

The increased compliance and reduced litigation are counterproductive, however, if a rule induces the wrong result. The age- 60 rule will deprive

34. On the conceptual difficulties in measurement of social utility, see Coleman, Efficienc;, Utility; and Wealth Maximization, 8 Horstra L. Rev. 509 (1980); Posner, Utilitarianism, Economics, and Legal Theory, 8 J. Legal Stud. 103, 112-17 (1979).

35. See G. Tullock, supra note 16; Ehrlich \& Posner, An Economic Analysis of Legal Rulemaking, 3 J. Legal Stud. 257 (1974). 
society of the services of safe, experienced sexagenarians. Even the claim that Model I has lower transaction costs must be tempered with skepticism. Arbitrary rules invite demands for modification. Proponents of Model I will spend their days defending the rule and may in the end accede to some exceptions. Processing petitions for waiver will consume many of the same social resources required for the administration of Model II.

Varying the degree of precision with which a rule is expressed can have an impact on both the primary behavior of the rule's audience and the transaction costs associated with administering the rule. ${ }^{38}$ Refining these concepts further, one can identify four principal subcategories of potential costs and benefits:

1. Rate of Compliance.-Increased precision may increase compliance and decrease evasion or concealment costs. First, it will reduce the cost of determining the rule's application to an actor's intended conduct. Second, the ease of enforcing transparent rules discourages would-be violators from making costly (and, from society's viewpoint, wasteful) efforts to avoid compliance. Increasing a rule's transparency may, however, eventually reduce compliance by increasing the cost of locating and applying the applicable provision, i.e., increasing the rule's inaccessibility and incongruence.

2. Over- and Under-Inclusiveness.-Increasing the transparency of a rule may increase the variance between intended and actual outcomes. The rulemaker may be unable to predict every consequence of applying the rule or to foresee all of the circumstances to which it may apply. While the rulemaker presumably can change the rule after learning of its incongruence, the process of amendment is costly and gives rise to social losses in the interim. On the other hand, a more opaque rule, though facially congruent, may be under- or overinclusive in application, because its vagueness invites misinterpretation. Increasing a rule's transparency may therefore substitute errors of misspecification for errors of misapplication.

3. Costs of Rulemaking.-Rulemaking involves two sorts of social costs: the cost of obtaining and analyzing information about the rule's probable impact, and the cost of securing agreement among participants in the rulemaking process. These costs usually rise with increases in a rule's transparency since objective regulatory linedrawing increases the risk of misspecification and sharpens the focus of value conflicts. Yet, greater initial precision can also reduce the need for future rulemaking by leaving fewer policy questions open for later resolution by amendment or case-by-case elaboration.

36. The classification used here is based loosely on that used by Ehrlich \& Posner, supra note 35. See also Gifford, Communication of Legal Standards, Policy Development, and Effective Conduct Regulätion, 56 CoRNell L. REv. 409, 466 (1971) (discussing "three-way relationship between resource expenditures, effectiveness of control, and substantive standards"). 
4. Cost of Applying a Rule.- The cost to both the regulated population and enforcement officials of applying a rule tends to increase as the rule's opacity or inaccessibility increases. Transparent and accessible rules can reduce the number of disputes that arise and simplify their resolution by causing the parties' predictions of the outcome to converge.

Having identified the costs and benefits associated with alternative rule formulations, the optimizing rulemaker computes the net social cost or benefit of each and selects the version generating the greatest net benefit.

\section{B. Balancing the Factors}

Classifying the consequences of alternative rules in this way helps identify situations in which one factor may exert especially strong pressures for transparency, accessibility, or congruence. The rate of compliance, for example, is an especially important consideration in the analysis of rules regulating socially harmful conduct. This factor supports use of highly transparent and accessible standards. By "strictly" construing the language used in criminal statutes according to its most widely accepted meaning, for example, courts enhance the transparency of the criminal law. ${ }^{37}$ One would similarly expect a high degree of transparency in the rules used to define easily concealable regulatory offenses such as unsafe transportation of hazardous chemicals ${ }^{38}$ unauthorized entry into the country, ${ }^{38}$ or overharvesting fisheries. ${ }^{40}$

Concerns about over- or under-inclusiveness dominate when errors of misclassification are particularly costly. The First Amendment "overbreadth" doctrine, for example, reflects a belief that speech often has a higher value to society than to the individual speaker." ${ }^{41}$ Similarly, the Supreme Court's concern about excessively rigid death penalty statutes reflects the very high cost it assigns to erroneous executions. ${ }^{42}$ Less dramatic examples also abound in administrative regulation. For example, the so-

37. See Dunn v. United States, 442 U.S. 100, 112-13 (1979); Hall, Strict or Liberal Construction of Penal Statutes, 48 Harv. L. Rev. 748, 756-62 (1935).

38. See Comptroller Gen. of the U.S., Programs for Ensuring the Safe Transportation of Hazardous Materials Need Improvement (Nov. 4, 1980); Comptroller Gen. of the U.S., Federal Actions ARe Needed to Improve Safety and Security of Nuclear Materials Transportation (May 7, 1979).

39. See Comptroller Gen. of the U.S., Prospects Dim for Effectively Enforcing ImMigration LaWs (Nov. 5, 1980).

40. See Comptroller Gen. of the U.S., Enforcement Problems Hinder Effective Implementation of New Fishery Management Activities (Sept. 12, 1979); Comptroller Gen. of the U.S., Progress and Problems of Fisheries Management Under the Fishery Conservation and Management Act (Jan. 9, 1979).

41. See, e.g., Central Hudson Gas v. Public Serv. Comm'n, 447 U.S. 557, 565-66 (1980); Gooding v. Wilson, 405 U.S. 518 (1972); $c f$. Monaghan, Overbreadth, 1981 SuP. CT. REv. 1 (discussing overbreadth as specific instance of challenge to third-party effects of rules).

42. See Woodson v. North Carolina, 428 U.S. 280, 305 (1976); Black, Due Process for Death, 26 
cial impact of discharging a given quantity of a pollutant into a stream can vary widely from industry to industry (because of variations in costs of prevention) or from stream to stream (because of variations in harm caused). ${ }^{43}$ Where the costs of over- or under-inclusiveness are high, rational policymakers will favor highly flexible or intricate regulatory formulas.

The costs of applying rules often loom especially large in the formulation of standards designed to govern a large volume of disputes. In these situations a desire to minimize litigation costs by using bright-line rules may outweigh countervailing considerations. Thus, agencies with particularly crowded enforcement dockets tend to adopt the most transparent rules. ${ }^{4}$ A related transaction cost is incurred in controlling the behavior of persons charged with a policy's enforcement. Numerous scholars have documented the difficulties of controlling the behavior of police officers and other officials applying law at the "street level."45 In occupational safety and health regulation or administration of the tax laws, which depend on large decentralized enforcement staffs, the costs of applying rules often push rules to a highly transparent extreme. ${ }^{48}$

The cost of rulemaking may assume particular saliency in a collegial rulemaking body such as a legislature or multi-member independent agency. ${ }^{47}$ The larger the number of participants and the more divergent their values, the greater will be the cost of reaching agreement. One would therefore expect collegial rulemakers to favor formulas like Model II, which minimize the range of agreement required. This effect is especially pronounced if the subsequent process of elaborating such open-ended rules has fewer participants.

The implication of this analysis is that optimal precision varies from

Cath. U.L. Rev. 1, 12 (1976); Radin, Cruel Punishment and Respect for Persons: Super Due Process for Dealh, 53 S. Cal. L. Rev. 1143, 1150 (1980).

43. See, e.g., Harrison, Regulation and Distribution, in AtTacking Regulatory Problems 185, 188-91, 200-01 (A. Ferguson ed. 1981); Spence \& Weitzman, Regulatory Strategies for Pollulion Control, in Appronches to Controlling Air Pollution 199, 204-11 (A. Friedlaender ed. 1978).

44. See Diver, The Assessment and Mitigation of Cizil Money Penalties by Federal Administralit'e Agencies, in Admin. Conf. of THE U.S., Recommendations and RePorTs, 1979, at 203, 223-83 (of four agencies studied, the Mine Safety and Health Adminstration, with the largest caseload, had the most transparent penalty standard).

45. Sep, e.g., M. Lipsky, Street Level Bureaucracy 145-46, 163-69 (1980) (private goal definition and unaccountability of police); J. Prottas, People Processing: The Street-Level Bureaucrat in Public Service Bureaucracies (1979) (describing behavior in welfare departments, public housing offices, hospitals, etc.); J. WiLson, VARIeties of PoliCE Behavior 57-82 (1968) (discussing police administration of patrolmen).

46. See Nichols \& Zeckhauser, Goternment Comes to the Workplace: An Assessment of OSHA, Pub. Interest, Fall 1977, at 39, 49; Smith, Protecting Workers' Health and Safety, in InSTEAd of Regul.ation: Alternatives to Federal Regulatory Agencies 311, 313-14 (R. Poole, Jr. ed. 1982).

47. Cf. Ehrlich \& Posner, supra note 35, at 267. 
rule to rule. The degree of precision appropriate to any particular rule depends on a series of variables peculiar to the rule's author, enforcer, and addressee. As a consequence, generalizations about optimal rule precision are inherently suspect. Nonetheless, one can use this framework to draw some general inferences about the relative precision of different types of rules. In the remainder of this section, I offer three illustrations based on distinctions between external and internal rules, between liability and sanctioning standards, and between prohibitory and licensure rules.

\section{Internal vs. External Rules}

Administrative rulemakers typically promulgate two kinds of rules: "external" rules addressed principally to the regulated public, and "internal" rules, addressed to persons charged with the enforcement of the external rules. ${ }^{48}$ There is often a substantial difference in the content of the two types of rules. Sometimes an internal rule directly contradicts an external rule. ${ }^{49}$ More commonly, internal rules seek to establish priorities for the allocation of resources to the enforcement of facially absolute commands.

Since they are addressed to different audiences and serve different functions, the two types of rules would be expected to have a different degree of precision. Because internal standards are fashioned to allocate resources ${ }^{80}$ concerns about incongruity will weigh heavily in the rule formulation. The socially optimal allocation of scarce prosecutorial resources, for instance, is a monumentally complicated matter, turning on a wide variety of factors. ${ }^{51}$ Simple, transparent rules may, therefore, grossly misallocate resources.

The putative gains from using transparent language, moreover, are likely to be smaller in the context of internal rules. Agency personnel are typically more homogeneous than the regulated public. The selection, training, and socialization of enforcement staff reduce the need to rely on internal standards to supply the education and motivation often provided by external standards. Since the audience for internal rules is also subject to more continuous and intensive supervision, the compliance-inducing function of rule precision is similarly less important.

These considerations provide support for the judiciary's customary re-

48. Sep id. at 261; cf. H.L.A. HART, supra note 8, at 77-96 (distinguishing "primary" from "secondary" rules).

49. Cf. R. Katzmann, Regulatory Bureaucracy 155-56 (1980) (FTC de-emphasis of

Robinson-Patman Act prosecutions).

50. Sep A. Downs, Inside Bureaucracy 59-63 (1967).

51. See Diver, A Theory of Regulatory Enforcement, 28 Puв. Poucy 257, 286-91 (1980); Rabin, Agency Criminal Referrals in the Federal System: An Empirical Study of Prosecutorial Discretion, 24 STAN. L. REV. 1036, 1044-72 (1972). 
luctance to interfere with the "internal management" of administrative agencies. ${ }^{82}$ Courts have displayed a great tolerance toward opaque prosecutorial policies, ${ }^{\text {s3 }}$ for example, despite frequent academic calls for reform. ${ }^{54}$ Our analysis cautions us not to be dismayed at this condition. It also suggests a basis for explaining occasional deviations from this deferential posture. The Supreme Court has, for instance, required most investigative agencies to establish relatively transparent policies for the conduct of regulatory inspections. ${ }^{55}$ Although such policies allocate internal investigative resources, they also regulate external conduct by instructing inspectors what to inspect and by advising regulated entities what to make available for inspection. Because most inspectors' work occurs at remote locations, moreover, close personal supervision is not a practical substitute for detailed written guidance. ${ }^{\text {sB }}$

\section{Sanctioning vs. Liability Rules}

Rules defining standards of criminal conduct tend to be relatively precise $^{\text {s7 }}$ while rules for determining appropriate punishment tend to be opaque. ${ }^{58} \mathrm{~A}$ similar divergence has been observed in civil regulation. ${ }^{59}$ Our framework suggests a basis for both this disparity and for the extreme deference that reviewing courts have accorded to administrative sanctioning decisions. ${ }^{60}$

52. Natural Resources Defense Council v. SEC, 606 F.2d 1031, 1046 (D.C. Cir. 1979) (dictum); see, e.g., Greater New York Hosp. Ass'n v. Mathews, 536 F.2d 494, 497-98 (2d Cir. 1976) (noting unreviewability of HEW Secretary's decision to change mode of reimbursement for Medicare services rendered by hospitals); Kletschka v. Driver, 411 F.2d 436, 444 (2d Cir. 1969) (noting unreviewability of Veterans Administration research grant).

53. Sep, e.g., Linda R.S. v. Richard D., 410 U.S. 614 (1973) (refusing to require prosecution of parent for failure to support illegitimate child); FTC v. Universal-Rundle Corp., 387 U.S. 244 (1967) (holding FTC's refusal to withhold enforcement of cease-and-desist order did not constitute patent abuse of discretion). But $f$. Adams v. Richardson, 480 F.2d 1159 (D.C. Cir. 1973) (en banc) (requiring HEW enforcement of Title VII against educational institutions); American Pub. Health Ass'n v. Veneman, 349 F. Supp. 1311 (D.D.C. 1972) (requiring FDA to release reports on efficacy of drugs and set deadlines for completion of further evaluations of efficacy).

54. See, e.g., K. DAvis, supra note 6, at 162-87; Vorenberg, Decent Restraint of Prosecutorial Discrelion, 94 Harv. L. Rev. 1521, 1560-72 (1981).

55. See Marshall v. Barlow's, Inc., 436 U.S. 307, 323 (1978) (search must be "pursuant to an administrative plan containing specific neutral criteria"); see also See v. City of Seattle, 387 U.S. 541 (1967) (requiring administrative subpoena to inspect warehouse); Camara v. Municipal Court, 387 U.S. 523 (1967) (requiring search warrants for nonemergency building inspection).

56. See, e.g., K. Hawkins, Environment and Enforcement chs. 7-8; J. Wilson, The Investigators: Managing FBI and Narcotics Agents 25 (1978).

57. SeP R. POSNER, supra note 12, at 425.

58. See, e.g., M. Frankel, Criminal. Sentences: Law Without Order (1973); P. O'Donnell, M. Churgin \& D. Curtis, Toward a Just and Effective Sentencing System: AGENDA fOR Legislative REFORM 3 (1977).

59. Diver, The Assessment and Mitigation of Cizil Money Penalties by Federal Administratiz'e Agencies, 79 Colum. L. Rev. 1435, 1457-59 (1979).

60. E.g., Butz v. Glover Livestock Comm'n Co., 411 U.S. 182 (1973); Professional Air Traffic Controllers Org. v. Federal Labor Relations Authority, 54 AD. L. REP. 2d 1, 58 (D.C. Cir. 1982); Nowicki v. United States, 536 F.2d 1171 (7th Cir. 1976), cert. denied, 429 U.S. 1092 (1977). 
First, many policymakers feel that encouraging compliance-an important function of precision-has little application to sanctioning standards. This sentiment in part reflects the modest range of most regulatory sanctions. When the range of options is known to be small, the marginal benefit of greater precision is commensurately small. Indeed, many regulators believe that imprecision is a better deterrent than precision, where actual penalties are modest. ${ }^{61}$

Drafters of sanctioning standards also face problems with congruence. The imposition of sanctions may serve several different objectives simultaneously such as general deterrence, special deterrence, compensation, retribution, incapacitation, or rehabilitation. ${ }^{62}$ Tailoring a standard to fit the relevant mix of objectives is often difficult. Even if one accepts general deterrence as the sole objective, the task is not greatly simplified. Effective deterrence demands a penalty based on the perceived probability of detection and conviction, the net gain to the violator from his violation, and the nonpenalty cost of violation. ${ }^{63}$ The same act, committed by different actors under different circumstances, may warrant widely divergent sanctions. Any transparent rule, therefore, is likely to produce both underdeterrence (by generating too low a penalty in many cases) and overdeterrence (by generating too high a penalty in others).

The distinction between liability rules and sanctioning rules is most apparent, however, in the area of transaction costs. Liability rules must be interpreted by the regulated population as well as persons involved in every level of enforcement. Since sanctioning rules apply only after a preliminary finding of liability, they are typically applied by a smaller group of officials (prosecutors and arbiters) and in a drastically reduced number of cases. As a consequence, the cost of applying sanctioning rules is smaller than the cost of applying liability rules.

The foregoing analysis suggests that, as a general rule, drafters of sanctioning rules will be less willing to compromise congruence to attain transparency and accessibility than drafters of liability rules. The analysis also suggests the proper characteristics to look for in seeking exceptions to this general tendency. For example, the larger the number of enforcement officials involved in the sanctioning process-and the greater the resulting

61. See Abrams, Internal Policy: Guiding The Exercise of Prosecutorial Discretion, 19 U.C.L.A. L. REv. 1, 29 (1971); Sofaer, Judicial Control of Informal Discretionary Adjudication and Enforcement, 72 Colum. L. Rev. 1293, 1297 (1972).

62. See F. Zimring \& G. Hawkins, Deterrence 71-90 (1973).

63. See Becker, Crime and Punishment: An Economic Approach, 76 J. Pol. Econ. 169 (1968); Polinsky \& Shavell, The Optimal Tradeoff Betueen the Probability and the Magnitude of Fines, 69 AM. ECON. Rev. 880 (1979); Stigler, The Optimum Enforcement of Laws, 78 J. POL. EcoN. 526, 530 (1970). 
cost of policing their conduct-the more transparent one would expect sanctioning rules to be. This helps to explain why agencies with huge caseloads and a highly decentralized enforcement process, like the Occupational Safety and Health Administration ${ }^{64}$ or the Mine Safety and Health Administration, ${ }^{6 B}$ have detailed penalty standards.

\section{E. Licensure Standards vs. Prohibitory Rules}

A third type of disparity explained by our analysis is the tendency of policymakers to formulate less transparent standards for issuing licenses than for direct prohibitions or commands. ${ }^{68}$ Licensure rules do not primarily deter or influence conduct. Rather, they seek to facilitate predictions about future conduct. They are, in this sense, addressed more to licensing officials than to the regulated population.

Licensure rules, moreover, are likely to pose greater difficulties in attaining congruence than liability rules because they tend to address relatively large and complex phenomena-such as the entry of a new competitor into an existing market-rather than isolated acts or omissions. Accurate estimation of social impact is bound to be correspondingly complex in scope and difficulty. Some licensing rules, moreover, seek to facilitate relative, rather than absolute, judgments. The question is not simply, "Is A socially beneficial?" but rather, "Which, among A, B, C, etc., is most socially beneficial?" Simple, transparent rules seem particularly prone to error in sorting out such calculations. ${ }^{67}$

A comparison of transaction costs in licensing and direct-conduct regulation yields an indeterminate result. Licensure cases are relatively infrequent because they deal with much lumpier issues. Yet such cases typically involve substantial individual stakes, because foreclosure from the licensed activity may involve substantial opportunity costs in foregone earnings.

These factors should induce drafters of licensing standards to give more weight to congruence and less to transparency and accessibility than do the authors of prohibitory rules. One would expect the strongest pressure for transparency in matters like occupational licensure or licensing motor vehicle operators, which involve a large volume of individual determinations, each having small social significance. In these settings, pressure to reduce transaction costs would push standards more in the direction of transparency, notwithstanding the cost in over- or under-inclusiveness.

\footnotetext{
64. Sep OSHA Field Operations Manual 81-93.

65. Sep 30 C.F.R. $\$ 100.3$ (1982); Diver, supra note 59, at 1447-52.

66. See Breyer, Analyzing Regulatory Failure: Mismatches, Less Restrictize Alternatizes, and Reform, 92 HARv. L. REv. 549, 575-76 (1979).

67. Sep G. Calabresi \& P. Bobbitt, Tragic Choices 72 (1978).
} 


\section{Four Case Studies of Rule Precision}

The foregoing categorical comparisons illustrate the insights that one can derive by using an efficiency model to evaluate rule precision. But insights at so high a level of generality provide little useful guidance to rulemakers and their overseers. The acid test for the efficiency criterion is its ability to support confident judgments about the precision of particular regulatory formulations.

To test the utility of our "precision calculus" as an evaluative framework, I apply it in this section to four specific administrative rules: the Federal Aviation Administration's retirement policy for commercial pilots, the Comptroller of the Currency's criteria for chartering national banks, the Social Security Administration's "grid" rules for disability determination, and the Immigration and Naturalization Service's standards for awarding permanent resident status to nonimmigrant aliens. The first three illustrate the three prototypical models sketched in Section I. Although the relative precision of each has been the subject of considerable public controversy, my analysis suggests that each represents a rational response to the particular demands of its regulatory context. The fourth case study, by contrast, highlights an administrative standard whose flaws fall into clear relief under the light of the precision framework.

\section{A. The Pilot Retirement Rule}

The Federal Aviation Act of 1958 authorized the Federal Aviation Administration (FAA) "to promote safety of flight of civil aircraft," giving "full consideration to the duty resting upon air carriers to perform their services with the highest possible degree of safety in the public interest." Among the more specific charges, the law instructed the FAA to develop "[r]easonable rules and regulations governing, in the interest of safety, the maximum hours or periods of service of airmen . . . ."68 The Act evinced a single-minded concern for the safety of air transportation.

As part of its program to implement the Act, the FAA promulgated the "age 60 rule" in 1959: "No individual who has reached his 60th birthday shall be utilized or serve as a pilot on any aircraft while engaged in air carrier operations." ${ }^{\text {"70 }}$ In explaining the basis for the rule, the FAA Administrator expressed concern about the "progressive deterioration of certain important physiological and psychological functions." Although the agency conceded that "available data do not permit any precise determina-

68. 49 U.S.C. $\$ 1421(a)-1421(b)(1976)$.

69. Id. $\S 1421(\mathrm{a})(5)$.

70. 24 Fed. Reg. 9773 (1959). For the current version, see supra note 28.

71. 24 Fed. Reg. 5247 (1959) (notice of proposed rulemaking). 
tion of the specific age at which continued activity as a pilot can be said conclusively to constitute a hazard to safety under normal or emergency conditions of flight, ${ }^{372}$ it chose a cutoff at age 60 for lack of any more defensible alternative. ${ }^{73}$

The rule has drawn recurrent criticism for its overinclusiveness. The rule's earliest and, until recently, most persistent critic was the Air Line Pilots Association (ALPA). After unsuccessfully opposing the rule's initial adoption, ${ }^{74}$ ALPA turned to the courts for relief. Its challenge to the rule's rationality in $A L P A v$. Quesada ${ }^{75}$ failed, however, producing instead this characteristically deferential judicial response: "It is not the business of courts to substitute their untutored judgment for the expert knowledge of those who are given authority to implement the general directives of Congress." ${ }^{\text {" }}$ Subsequent efforts to enlist judicial support in the attack on the rule have proved equally unavailing. Encouraged by a suggestive footnote in the Quesada case, ${ }^{77}$ several pilots petitioned the FAA for exemption from the retirement rule pursuant to a statutory provision that authorizes the Administrator to "grant exemptions . . . if he finds that such action would be in the public interest." nied all petitions for exemption without hearing and has been uniformly upheld on appeal. ${ }^{79}$

Having failed to secure relief from the agency or the courts, ALPA approached Congress. After a decade of unsuccessful lobbying, ALPA finally persuaded Congress to direct a study of the rule's medical justification by the National Institutes of Health. ${ }^{80}$ But the study panel's report, released two years later, concluded that the rule should be retained. ${ }^{\mathbf{8 1}}$ After examining a wide array of medical and performance simulation tests, the panel found none able to predict loss of function with sufficient accuracy to replace the simple age criterion. ${ }^{82}$

The age 60 rule is pure Model I: almost perfectly transparent and ele-

72. Id. at 5249 .

73. Id. at 9772 .

74. See Comment, Mandatory Retirement of Airline Pilots: An Analysis of the FAA's Age 60 Retirement Rule, 33 Hastings L.J. 241, 245-46 (1981).

75. 276 F.2d 892, 898 (2d Cir. 1960).

76. Id.

77. Id. at 898 n.10.

78. 49 U.S.C. $§ 1421$ (c) (1976).

79. Keating v. FAA, 610 F.2d 611 (9th Cir. 1979); Gray v. FAA, 594 F.2d 793 (10th Cir. 1979); Starr v. FAA, 589 F.2d 307 (7th Cir. 1978); see also O'Donnell v. Shaffer, 491 F.2d 59 (D.C. Cir. 1974) (finding no requirement for adjudicatory hearing in denying petitions to revoke age 60 rule).

80. Pub. L. No. 96-171, 93 Stat. 1285 (1979) (codified at 49 U.S.C. $\S 1421$ (Supp. V 1980)).

81. NIA REPORT, supra note 29. The report acknowledged that "there is no convincing medical evidence to support age 60 , or any other specific age, for mandatory pilot retirement." Id. at 2 . But it did conclude, from examining "available actuarial and epidemiological data," that the probability of "accident attributed to acute or subtle incapacitation" of pilots would increase with pilot age. Id. 82. See id. at 4,7 . 
mentally simple. Model I formulations are likely to seem especially attractive when enforcement is particularly difficult or costly. This consideration might have motivated the FAA in 1959, even though its official explanation for the rule makes scant mention of it. ${ }^{83}$ Involuntary retirement can exact a heavy toll on the unwilling pilot in forgone income ${ }^{84}$ and loss of professional satisfaction or self-esteem. Many pilots might go to considerable lengths to avoid the rule. A bright-line retirement standard offers a promising way to minimize the costs of combatting evasion.

In fact, however, the risk of evasion could not have appeared substantial. Piloting commercial aircraft is a visible activity, and the FAA could count on the carriers to help it police any reasonable retirement policy. ${ }^{\mathrm{gs}}$ The transaction-cost savings argument is more telling. Disqualification from piloting commercial aircraft is a sufficiently severe deprivation to warrant a hearing of contested issues. Enforcement of a discretionary retirement standard, consequently, could generate expensive proceedings involving a high proportion of the pilots to whom it was applied. Although the number of commercial pilots approaching retirement in 1959 was small, the FAA correctly foresaw a substantial increase in their numbers. ${ }^{88}$

Set against this modest saving in enforcement costs, one must consider the incongruity losses occasioned by the use of a sharp dividing line. Prematurely grounding healthy pilots can involve two complementary forms of social cost: (1) the cost of training replacements, and (2) the additional accidents caused by insufficiently trained replacements. At the time of the rule's adoption, these costs did not appear particularly great. The airline industry was beginning to introduce turbojet aircraft into commercial aviation on a large scale in the late 1950's. Operation of the new aircraft, even by experienced pilots, required extensive training. In fact, far from being concerned about the cost of replacing experienced pilots, the FAA expressed doubt whether any amount of retraining could break senior pilots of old habits completely enough to assure proper response in emergencies. ${ }^{87}$

83. 24 Fed. Reg. $9772-73$ (1959).

84. Today, pensions average about $50 \%$ of pre-retirement salaries. For captains employed by major airlines, the resulting loss of income ranges from $\$ 30,000$ to $\$ 50,000$. NIA REPORT, supra note 29, app. C, at C-73 to C-74 (statement of Air Transport Ass'n). The financial impact of retirement in 1959 was more severe since pensions were relatively less generous.

85. Air carriers, which generally wish to maintain good relations with the FAA, have consistently supported mandatory retirement at age 60 . See id. at C-51 (statement of Air Transport Ass'n).

86. See 24 Fed. Reg. 5248 (1959) (80 airline pilots expected to reach age 60 by 1962). In the 1980's, "between 500 and 1000 airline pilots will reach age 60 each year." Report of the Instilute of Medicine, Airline Pilot Age, Health and Performance: Scientific and Medical Considerations (Mar. 1981), in NIA REPORT, supra note 29, at F-32.

87. 24 Fed. Reg. 9773 (1959). 
A second reason for the FAA's apparent disregard of incongruity costs was the lack of any discriminant better than age. ${ }^{88}$ Granted, the FAA seemed to agree that age is only a crude proxy for incapacitating conditions. But it does no good to bemoan the crudeness of that proxy unless a better predictor can be found.

If the case for the rule's original adoption rests heavily on the introduction of turbojet aircraft and the infancy of medical science, what factors justify the rule's retention in 1983? The calculus clearly has changed. Transaction costs provide an even weightier argument for a Model I rule now, with 500 to 1000 airline pilots reaching 60 each year. ${ }^{89}$ Yet the potential losses occasioned by a hard-and-fast age discriminant have also increased. No dramatic revolution in aircraft technology threatens the present generation of senior pilots with obsolescence. At an estimated cost of $\$ 250,000^{80}$ to train a new pilot, the replacement tradeoff begins to look less favorable than it did in 1959.

Time has also eroded the "lack of alternatives" argument. Much progess has been made in developing reliable measures for many important physiological functions. ${ }^{21}$ Yet, as testing techniques have become more sophisticated, so has our appreciation of the conditions for successful pilot performance. There remain more critical functions, especially intellectual and psychological ones, for which no better discriminant than age has been found. ${ }^{22}$ Recent progress in developing testing procedures, in short, cannot guarantee the reduction in the volume of unnecessarily grounded pilots that a more individualized screening process might ordinarily generate.

The ultimate balance is not easy to strike. ${ }^{93}$ One can say with assurance only that in the twenty-four years since 1959, the stakes have risen on both sides of the dispute. The number of skilled pilots languishing in premature retirement is unquestionably much greater today, but, then, so is the number of lives that a more individualized screen would unavoidably entrust to aging pilots with undetectable risks. In the weighing of such imponderables, even a modest saving in transaction costs is justification enough to retain the present rule.

\section{B. National Bank Chartering Standards}

Compared to the FAA's retirement rule, the criteria used by the Comp-

88. Id.

89. See supra note 86.

90. NIA REPORT, supra note 29, app. C, at G-37 (statement of Air Line Pilots Ass'n).

91. Sep id., app. F, at F-23 to F-26.

92. Id. at $\mathrm{F}-20$.

93. For that very reason, the FAA's recent decison to reopen the issue for more systematic reappraisal is most welcome. See 47 Fed. Reg. 29,782 (1982) (advance notice of proposed rulemaking). 
troller of the Currency to charter national banks are a study in ambiguity. The Comptroller of the Currency derives his authority to grant charters to national banks from the National Bank Act of $1864 .^{94}$ Throughout the period since the Act's adoption, Comptrollers have made very little effort to confine their virtually unrestricted statutory discretion by articulating more precise criteria for chartering decisions. Prior to 1976, the Comptroller's published policy statements merely listed five factors that would be investigated in the course of processing an application:

(1) The adequacy of the proposed bank's capital structure;

(2) The earning prospects of the proposed bank;

(3) The convenience and needs of the community to be served by the proposed bank;

(4) The character and general standing in the community or [sic] the applicants, prospective directors, proposed officers, and other employees, and other persons connected with the application or to be connected with the proposed bank; and

(5) The banking ability and experience of proposed officers and other employees. ${ }^{95}$

Virtually no "common law" of bank chartering evolved, moreover, since Comptrollers furnished little or no explanation for their decisions. ${ }^{\circ b}$

This state of extreme regulatory opacity led Professor Kenneth Scott, in a 1975 study, to criticize the Comptroller for failing to "provide a clear and consistent explanation of what he is doing."'97 Based on Scott's report, the Administrative Conference of the United States recommended that the bank chartering agencies, including the Office of the Comptroller of the Currency (OCG), "undertake to provide a full statement of their objec-

94. Act of June 3,1864 , ch. 106, 13 Stat. 99 (codified in relevant part at 12 U.S.C. \$§ 21-27 (1976)). The only substantive standard for bank chartering in the Act is:

If . . . it appears that such association is lawfully entitled to commence the business of banking, the comptroller shall give to such association a certificate . . . . But the comptroller may withhold from an association his certificate authorizing the commencement of business, whenever he has reason to suppose that the shareholders have formed the same for any other than the legitimate objects contemplated by this chapter.

12 U.S.C. $\$ 27$ (1976).

The Federal Deposit Insurance Act of 1935, 12 U.S.C. § 1816 (1976), augmented this sparse language modestly. Since national banks must have deposit insurance, a charter applicant must satisfy the Act's standard for insurability. But this standard merely enumerates six factors to be considered by the Comptroller: the financial history and condition of the bank, the adequacy of its capital structure, its future earnings prospects, the general character of its management, the convenience and needs of the community to be served by the bank, and whether its corporate powers are consistent with the purpose of the act.

95. 12 C.F.R. § 4.2(b) (1974).

96. Scott, In Quest of Reason: The Licensing Decisions of the Federal Banking Agencies, 42 U. Chi. L. Rev. 235, 261-68 (1975).

97. Id. at 268 . 
tives in approving or denying applications for charters . . . and . . . define in concrete terms the standards to be applied."

On June 4, 1976, the Comptroller responded by publishing in the Federal Register a document entitled "Policy Statements on Corporate Activities." "99 The statement articulated an overarching policy goal for bank chartering-"to maintain a sound national banking system without placing undue restraint upon entry into that system." The statement imposed several constraints on the pursuit of this goal: avoiding the chartering of "so many banks that none can grow to a size sufficient to offer a full range of needed services," admitting "only those qualified applicants that can be economically supported and profitably operated," and protecting the "viability" of newly chartered independent banks.

The policy statement went on to enumerate four "banking factors" ("income and expenses," "management," "stock distribution," and "capital"), five "market factors" ("economic condition and growth potential," "primary service area," "location," "population," and "financial institutions"), and several "other factors" to be considered in evaluating an application. Although the guidelines included a few objective tests for stock distribution and adequacy of capital, ${ }^{100}$ most of the relevant factors were expressed in highly conclusory terms with no indication of their relative weights. ${ }^{101}$

Predictably, the 1976 policy statement did not still the Comptroller's critics. The Senate Banking Committee concluded in 1980 that: "OCC's reliance on vague chartering standards . . . [has] exposed the chartering process to charges of favoritism and arbitrary decision making." ${ }^{102}$ To support its characterization, the study cited the high rate of disagreement among internal OCG reviewers and alleged inconsistencies in handling specific cases. ${ }^{103}$ Finding OCG's economic projections to have been wide of the mark in several instances, the committee concluded that the "community need" criterion "is a poor indicator of a new bank's likely prospects"104 and proposed greater reliance on factors relating to organization and management.

Almost simultaneously with release of the Committee report, the Comptroller issued a revised policy statement. The statement spoke of "clarifying" previous policy and "facilitat[ing] applicant and public un-

98. AdMIN. Conf. of the U.S., Recommendation 75-1(1), 1 C.F.R. $§ 305.75-1(1)$ (1977).

99. 41 Fed. Reg. 47,964 (1976).

100. Two examples are a limit of $10 \%$ stock ownership by any one person and minimum capital of $\$ 1,000,000$. Id. at 47,965 .

101. For example, the applicant's officers must have "reputations evidencing honesty and integrity. They should have employment and business histories demonstrating success, and should be responsible in financial affairs." Id. at 47,964-65.

102. Majority Staff Study, supra note 3, at iv.

103. Id. at $18-19,33$.

104. Id. at 55 . 
derstanding," 105 but its principal function was to announce a shift toward a more competitive bank entry policy. ${ }^{106}$ As an exercise in policy "clarification," the 1980 statement accomplishes little. While the sheer volume of words has increased since 1976, the few earlier per se rules relating to stock ownership and capitalization have been replaced with vague rule-ofreason language (e.g., "sufficient" capital, ${ }^{107}$ "wide distribution of stock"108). Aside from lowering the "community need" barrier to entry, ${ }^{109}$ the policy statement provides little guidance to individual applicants.

The Comptroller's persistent reliance on an opaque Model II approach should neither surprise nor dismay us. First, the likelihood that per se rules will produce costly incongruities seems high, if one assumes-as Comptrollers emphatically have-that the overriding purpose of entry restrictions is to maintain public confidence in the banking system by reducing the risk of failure. The likelihood that new entry will cause economic dislocation and erosion of confidence-either through the entrant's failure or by weakening an incumbent-seems to depend on a host of variables relating to the entrant's capabilities, its competitors' positions, and market conditions. These factors will vary widely from market to market, and the history of chartering suggests that they can change markedly with shifts in economic conditions. ${ }^{110}$

Encouraging compliance, moreover, seems largely irrevelant here. Chartering standards are not aimed at modifying behavior. Their sole function is to guide the selection of applicants who are qualified to be admitted to the banking industry. It is true, of course, that the relative transparency of standards may influence the rate of applications and, consequently, the rate of entry. More precise criteria would reduce uncertainty and might encourage applications from those dissuaded by the high costs of compiling the necessary economic data. During a time of per-

105. 45 Fed. Reg. 68,603 (1980).

106. Statistics on the Comptroller's charter approval rate show that this policy shift had occurred well before the 1980 policy statement. The approval rate, which had fallen below $50 \%$ in 1977 , increased to $88 \%$ in 1980. See Office of The Comptroller of THe Currency, 1980 AnNual Report 240 (1980); Office of the Comptroller of THe Gurrency, 1977 annual. Report 7 (1977).

107. 12 C.F.R. $\$ 5.20$ (c)(3)(iii) (1982).

108. Id. $\S 5.20(\mathrm{c})(3)(\mathrm{iv})(\mathrm{B})$.

109. For an empirical demonstration that the "need" criterion "significantly reduced the entry rate into banking," see Peltzman, Entry into Commercial Banking, 8 J. L. \& EcoN. 11, 48 (1965).

110. Edwards \& Edwards, Measuring the Effectiveness of Regulation: The Case of Bank Entry Regulation, 17 J. L. \& ECON. 445, 452 (1974). OCC's charter approval rate has fluctuated from lows of $18 \%$ in 1965 and 1967 , to a high of $66 \%$ in 1973 , then down to a low of $45 \%$ in 1977 , and again dramatically upward since then. Sep OfFICE OF THE COMPTROLLER OF THE CURRENCY, 1973 ANNuAl. Report 5, 7 (1973); Office of the Comptroller of the CurRency, 1967 AnNual. RfPort 8 (1967); OfFice of the Comptroller of the CuRrency, 1965 ANNUAl Report 22 (1965); supra note 106. 
ceived inadequacy of banking services, this factor might exert a stronger pull toward greater transparency.

The evidence does not support this thesis, however. The 1976 policy statement-the high-water mark of OCC charter rule precision-is far more protectionist in tone than the 1980 rules, and was issued by a Comptroller whose charter approval rates were the lowest in the decade. Furthermore, Comptrollers who wish to encourage new entry can often encourage applications far more efficiently by making procompetitive public statements than by issuing rule changes. ${ }^{111}$

Transaction costs similarly offer little support for a high degree of precision. The costs of applying the rules are not substantial. The Comptroller received, on average, only about 120 formal charter applications per year during the 1970's. The process for deciding cases is highly informal, usually consisting of only a field examination and several internal reviews. While organizers often have a sufficient stake in the outcome to demand far more elaborate procedures, the courts and Congress have resisted pressures to impose them. ${ }^{112}$ The opportunity for applicants to reapply or to seek entry through the state regulatory system undoubtedly mitigates those pressures. Furthermore, the decisionmaking is highly centralized. Even after receiving blanket legislative authority in 1980 to delegate any power vested in his office by law, ${ }^{113}$ the Comptroller has maintained tight central control over chartering decisions. ${ }^{114}$ This longstanding tradition of centralized decisionmaking has substantially reduced the pressure to use clear rules to control agency decisionmakers.

The cost of rulemaking similarly cuts against increased transparency. If it is true that the risks of incongruity are serious, the cost of developing a transparent, yet congruent, rule would be quite high. Preliminary efforts by staff economists to produce more rigorous models for predicting economic impact have been discouraging. ${ }^{115}$ Nor does the Comptroller face as great a tradeoff between ex ante and ex post policymaking costs as other agencies, given the informality of the charter decisionmaking process and the minimal explanation for rejections demanded by reviewing courts.

In sum, the degree of precision with which Comptrollers have articulated charter policy, especially since 1976, seems fully consistent with the context in which they operate. This is not to say that the substantive policy assumptions or the procedural informality associated with the regula-

111. For an asserted illustration, see MAjoRITY Staff STUdy, supra note 3, at 7-8 (Comptroller James Saxon at the beginning of his tenure in 1962-1963).

112. Spe Scott, supra note 96.

113. 12 U.S.C. $\S 4 a$ (Supp. V 1981).

114. Spe 12 C.F.R. $\S 5.3$ (1981).

115. Interview with John Schockey, former OCC General Counsel (Jan. 10, 1981) (notes on file with author). 
tion of bank entry are necessarily defensible. ${ }^{116}$ But in a system built on these features, a substantial increase in charter rule precision would probably not produce benefits justifying its cost.

\section{The Disability Insurance "Grid" Rule}

The Social Security Disability Insurance (DI) Program pays benefits to wage earners and their dependents enrolled in the Social Security programs who lose their jobs as the result of a "disability." Since the program's inception in 1957, the definition of a "disability" has undergone repeated administrative revision and elaboration. ${ }^{117}$ This evolution culminated in 1978 with adoption of the so-called "grid" rule-a complex formula that specifies how various physical and vocational attributes of claimants are to be integrated into the ultimate disability determination. ${ }^{118}$ As a prototypical Model III rule, the grid rule has drawn intense criticism for its alleged incongruity and inaccessibility. ${ }^{118}$

The Social Security Act of 1956 defined "disability" quite simply as "inability to engage in any substantial gainful activity by reason of any medically determinable physical or mental impairment which can be expected to result in death or to be of long-continued and indefinite duration."120 Although the statutory formula has been revised several times, ${ }^{\mathbf{1 1 1}}$ it still delegates primary responsibility to the Social Security Administration (SSA) to elaborate the meaning of "disability." Before 1978, SSA devoted most of its attention to "physical and mental impairment," developing detailed guidelines for measuring impairments and defining several "per se disabling" conditions. ${ }^{122}$ The nonmedical criteria for determining "inability to engage in substantial gainful activity," however, remained

116. See, e.g., Alhadeff, A Reconsideration of Restrictions on Bank Entry, 76 Q.J. EcoN. 246 (1962); Tussing, The Case of Bank Failure, $10 \mathrm{~J}$. L. \& EcoN. 129 (1967). The policies behind these regulations show no signs of yielding.

117. For a more detailed account, see J. Mashaw, Bureaucratic Justice: Managing Social SfCuRITY Disabil.tTy Glaims 103-23 (1983).

118. 43 Fed. Reg. 55,366 (1978) (codified at 20 C.F.R. subpt. P app. 2 (1983)).

119. Litigation concerning the validity and application of the grid rules has been prolific. Most circuits have upheld the rules. See Rivers v. Schweiker, 684 F.2d 1144 (5th Cir. 1982); McCoy v. Schweiker, 683 F.2d 1138 (8th Cir. 1982); Torres v. Secretary of Dep't of Health \& Human Servs., 677 F.2d 167 (1st Cir. 1982); Santise v. Schweiker, 676 F.2d 925 (3d Cir. 1982); Cummins v. Schweiker, 670 F.2d 81 (7th Cir. 1982); Frady v. Harris, 646 F.2d 143 (4th Cir. 1981). The Supreme Court reversed the two circuits that had partially invalidated the rules. Heckler v. Campbell, 103 S. Ct. 1952 (1983) (reversing Campbell v. Secretary of Health \& Human Servs., 665 F.2d 48 (2d Cir. 1981)); Heckler v. Broz, 51 U.S.L.W. 3857 (U.S. May 31, 1983) (vacating Broz v. Schweiker, 677 F.2d 1351 (11th Cir. 1982)).

120. Act of Aug. 1,1956 , ch. $836, \S 103$ (a), 70 Stat. 807,815 (codified as amended at 42 U.S.C. $\S$ 423(d) (1976)).

121. Act of Sept. 13, 1960, Pub. L. No. 86-778, $\S 401$ (a), 74 Stat. 924, 964; Act of July 30, 1965, Pub. L. No. 89-97, $\S 303$ (a)(2), 79 Stat. 286, 367; Act of Jan. 2, 1968, Pub. L. No. 90-248, $§ 158(b)$, 81 Stat. 821,868 .

122. 22 Fed. Reg. 4362 (1957); 26 Fed. Reg. 5572 (1961); 33 Fed. Reg. 11,749 (1968). 
clouded in imprecise verbiage. ${ }^{123}$ Congress amended the Act in 1968 to require SSA to consider the applicant's "age, education, and work experience" in making the disability determination. ${ }^{124}$ Until 1978, however, the assessment of these factors was consigned to the judgment of claims processing officials, who relied heavily on the professional opinion of vocational experts. ${ }^{125}$

The grid rule substituted a mechanical formula for the previously individualized process in a large number of disability cases. ${ }^{126}$ The grid specifies the relationships among four independent variables (the claimant's "exertional capabilities," "education," "age," and "previous work experience") and the dependent variable ("disability"). ${ }^{127}$ Each of the independent variables can take several possible values-for example, there are four "age" categories ("advanced," "closely approaching advanced," "younger (45-49)," and "younger (18-44)"), and three "experience" groupings ("unskilled or none," "skilled or semiskilled-skills not transferable," and "skilled or semiskilled-skills transferable"). For each combination of these variables, the rule specifies the ultimate decision ("disabled" / "not disabled").

The grid rule is the latest stage in a relentless progression toward transparency and complexity in the disability standard. The factor most obviously responsible for this trend is transaction costs. ${ }^{128}$ The volume of determinations is immense and was, until recently, growing at a rapid rate. The number of hearings is still growing. ${ }^{129}$ Moreover, although the average cost of processing all DI claims is modest ( $\$ 171$ in $\left.1978^{130}\right)$, the cost per contested claim is a good deal higher. ${ }^{131}$ The total administrative

123. Only the earnings test is reasonably transparent. See 26 Fed. Reg. 11,049, 11,051 (1961) (codified as amended at 20 C.F.R. $\$ 404.1574-.1575$ (1982)).

124. Act of Jan. 2, 1968, Pub. L. No. $90-248, \S 158($ b), 81 Stat. 821,869 (inserted in 42 U.S.C. $\S 423(\mathrm{~d})(2)(\mathrm{A})(1976))$.

125. For a description of the handling of claims, see R. Dixon, Social Security Disabilrty and Mass Justice 24-30 (1973).

126. The rule applies only to disability claims grounded on "exertional" incapacity. After eliminating claims based on per se disabling conditions (e.g., blindness, loss of limbs), most claims fall within this category.

127. 20 C.F.R. subpt. P app. 2 (1983).

128. Since the rules are intended solely to characterize a status resulting from an unexpected and presumably unwanted cause, their evolution cannot plausibly be related to any compliance-related goals. Their only possible behavioral objective would be to discourage malingerers from filing claims, an effect that would be reflected in a reduction of transaction costs.

129. Staff of Senate Comm. on Finance, 97th Cong., 2d Sess., Staff Data and Materials Related to the Social Security Disability Insurance Program 20-29, 69-72, 145-46 (Comm. Print 1982). From 1974 to 1981, DI applications dropped slightly from 1.33 million to 1.23 million, id. at 21-22, while hearing requests increased from 121,504 to 281,700 , id. at $69-70$.

130. Social Sec. Admin., 1978 SSA Year in Review: Administration of Social Security Program 12 (1978).

131. One study estimated the cost per hearing at $\$ 500$ to $\$ 1000$. J. MaShaw, C. Goetz, F. Goodman, W. Schwartz, P. Verkull \& M. Carrow, Social Security Hearings and apPEALS 15 (1978). 
cost of the disability insurance system in 1978 was $\$ 327$ million. ${ }^{132}$

Raw numbers like these fail to do full justice to the importance of transaction costs. A "hidden" transaction cost in any benefits system is the impact of delay on deserving applicants. The 551,500 applicants who received a favorable decision in 1976, for example, had to wait an average of 105 days for the award. ${ }^{133}$ The human costs of anxiety and deprivation from such delays are enormous.

A second hidden transaction cost is the difficulty of controlling subordinate decisionmakers. A substantial degree of de facto decentralization is unavoidable in so enormous an operation. But the structure of the DI program promotes decentralization with a vengeance. Initial decisions (which become final determinations in the eighty-five percent of cases not appealed to SSA) are made by officers of fifty autonomous state agencies who are subject only to indirect supervision by SSA. ${ }^{134}$ These state agencies themselves are often administratively decentralized and rely heavily on consulting physicians and vocational experts. ${ }^{135}$ Within SSA, decisions are made by a cadre of about seven hundred fiercely independent Administrative Law Judges (ALJ's) who preside at hearings where there are usually no representatives of SSA present. ${ }^{136}$ Any decisionmaking apparatus so fragmented-especially one which affects such large sums of money and so many people-cries out for tight, centralized control. Recent studies documenting inconsistencies among state agencies and ALJ's have intensified pressures for reform. ${ }^{137}$

Demands for tighter supervision naturally focus attention on the clarity of substantive standards. The utility of conventional management control devices like reporting systems, performance appraisal, and quality review $^{138}$ ultimately depends on the transparency of the underlying standards to be applied. ${ }^{138} \mathrm{It}$ is one thing to document inconsistency in results by comparing two individuals' resolutions of a hypothetical case. ${ }^{140}$ But it

132. H.R. RE.P. No. 100, 96th Cong., 1st Sess. 19 (1979).

133. Social. Sec. Admin., 1977 SSA ANnual Report 20 (105-day mean processing time for allowed claims as of October 1976); Staff of Senate Comm. ON Finance, supra note 129, at 21 (number of claims awarded).

134. Social. SEc. Admin., supra note 133, at 52.

135. Sep R. Dixon, supra note 125, at 35-40.

136. See Bloch, Representation and Advocacy at Non-Adversary Hearings: The Need for NonAdtersary Representatizes at Social Security Disability Hearings, 59 WASH. U.L.Q. 349, 356-66 (1981).

137. See J. Mashaw, C. Goetz, F. Goodman, W. Schwartz, P. Verkuil \& M. Carrow, supra note 131, at 3-4; Champagne \& Danube, An Empirical Analysis of Decisions of Administrative Lau Judges in the Social Security Disability Program, 64 Geo. L.J. 43 (1975).

138. SSA's quality-control system is described in J. MASHAW, supra note 117, at 145-68 and Chassman \& Rolston, Social Security Disability Hearings: A Case Study in Quality Assurance and Due Process, 65 Cornell L. Rev. 801 (1980).

139. Sep R. Dixon, supra note 125 , at 51 .

140. This technique was used in Secretary of Health \& Human Seris., Implementation of Section 
is very difficult to remedy that inconsistency without having clear criteria. Without the dramatic increase in regulatory objectivity, SSA's massive quality control program and its impressive quantitative ${ }^{141}$ gains would be almost unthinkable.

Transparency is usually bought at the price of incongruity or ex ante rulemaking costs. To take the latter first, the development of SSA's elaborate scheme has undoubtedly been costly. But failure to develop generic criteria would merely postpone, not avoid, rulemaking costs in a program that has always required elaborate justification for individual decisions. Disappointed recipients are entitled to increasingly thorough and coherent explanations at successive levels. Formal hearing procedures (at the ALJ stage $)^{\mathbf{1 4 2}}$ and searching judicial review ${ }^{\mathbf{1 4 3}}$ together impose a particularly rigorous justificatory burden on those who deny claims at the appellate stage. A legalistic system for processing claims will reward heavy initial investment in a priori rulemaking by reducing the cost of meeting its subsequent explanatory obligation.

The incongruity argument is more troublesome. The current rules undoubtedly miss their target with some frequency. ${ }^{144}$ Can it be true, for example, that no person in his late 40's who is unskilled, uneducated, and limited to sedentary work, can be "disabled"?145 Yet, despite such troubling examples, the true cost of misclassifying a case depends on how close the case is to the boundary between "disabled" and "not disabled."146 A regime that misclassifies 100,000 healthy malingerers or immobile quadriplegics is far more costly to society than one that misclassifies 100,000 potentially handicapped persons. The latter, if granted benefits,

304(g) of Public Law 96-265, "Social Security Disability Amendments of 1980" (January 1982) ("The Bellmon Report"), reprinted in STaff of Senate Comm. on Finance, supra note 129, at 133.

141. For example, processing time has dropped steadily in recent years. The mean time for initial awards dropped from 110 days in 1976 to 85 days in 1978. Social SEC. ADMIN., supra note 130, at 12. Mean processing time for ALJ hearings fell from 249 days in 1976 to 145 days in 1979. SociaL SEc. Admin., 1979 SSA ANnual RePort 59 (1979). The "productivity index," SSA's overall measure of productivity in processing DI cases, increased from 100 in 1967 to 145 in 1976. SOctaL SEC. ADMIN., supra note 130 , at v.

142. See Mathews v. Eldridge, 424 U.S. 319, 339, 349 (1976) (post-termination evidentiary hearing adequate safeguard of claimants' rights).

143. See Echevarria v. Secretary of Health \& Human Servs., 685 F.2d 751, 756 (2d Cir. 1983) (reversing SSA's denial of benefits because ALJ did not fulfill his "special duty to pro se claimants").

144. See Goldhammer, The Effect of the New Vocational Regulations on Social Security and Supplemental Security Income Disability Clains, 32 AD. L. REv. 501, 502-03 (1980) (discussing omissions from SSA's list of impairments).

145. 20 C.F.R. subpt. P app. 2, § 201.17 (1983); see Broz v. Schweiker, 677 F.2d 1351 (11th Cir. 1982) (criticizing mechanistic use of grid regulations but approving their use as burden-shifting tool), zacaled and remanded sub nom. Heckler v. Broz, 51 U.S.L.W. 3857 (U.S. May 31, 1983).

146. See Mashaw, How Much of What Quality?: A Comment on Conscientious Procedural Design, 65 CORNELL L. REv. 823, 824-28 (1980) (discussing relationship between closeness of case and its cost). 
may forgo only limited productive effort, and, if denied benefits, may have some hope for independent support. The relevant question then becomes whether the unavoidable incongruities of a bright-line rule cluster near the dividing line or near the extremes. As Professor Jerry Mashaw shows, under SSA's current regime, the incongruities cluster near the dividing line. ${ }^{147}$ SSA's decision rule uses simple, transparent tests to eliminate the easy cases at both extremes, reserving the closer cases for resolution under more refined criteria. ${ }^{148}$ Intuitively, at least, the grid seems to embrace within the company of the disabled the most deserving cases.

Moreover, while the rule contains many more bright lines than before, it still contains strategically located discretionary judgments, such as the threshold severity-of-impairment determination, ${ }^{149}$ the "medical equivalence" test for unusual medical impairments, ${ }^{150}$ and the classification of a claimants' "residual functional capacity."151 The flexibility afforded by these assessments enables decisionmakers to avoid egregiously unjust applications of the rule. On this impressionistic level, the SSA rules seem to hold incongruity costs within tolerable limits.

This brings us back to transaction costs, since the rules achieve their objective only at the cost of enormous complexity. Does not the sheer difficulty of the decision rule compensate, in added fact-finding and interpretive efforts, for the savings effected by increased transparency? The answer here seems to be, "No." First, because the rule does not announce a standard of behavior, ${ }^{152}$ its complexity has no adverse effect on private planning. Second, most of the effort currently expended on gathering medical and vocational information in processing a claim would still be required under a superficially simpler standard. And since most cases raise only a few contestable issues, the overall complexity of the rules is less important than their accessibility and transparency. In these latter respects, SSA's rules receive a high score.

\section{INS Change-of-Status Policy}

Until 1952, aliens visiting the United States on non-immigrant visas who wished to remain had to return to their native lands to obtain an immigrant visa from the United States Consul. ${ }^{153}$ To relieve the burden of

147. See Mashaw, Administrative Due Process as Social-Cost Accounting, 9 Hofstra L. Rev. 1423, 1441 (1981).

148. 20 C.F.R. $\S 404.1520$ (1983).

149. Id. $\S 404.1520$ (c).

150. Id. $\S 404.1520$ (d).

151. Id. § 404.1545-.1546.

152. See supra note 128 .

153. These aliens had to return to their country even if they were immediately eligible for such a visa. See Sofaer, The Change-of-Status Adjudication: A Case Study of the Infornal Agency Process, 1 J. Legal Stud. 349, 350-51 (1972). 
that requirement, Gongress authorized the Attorney General, "in his discretion" and "under such regulations as he may prescribe," to adjust the status of some aliens to that of "an alien lawfully admitted for permanent residence."154

To qualify for adjustment of status, the applicant must meet several statutory criteria, including immediate eligibility for an immigrant visa under applicable quotas. ${ }^{155}$ These threshold criteria are either facially transparent or well articulated by a history of interpretation. The additional "discretionary" element of the determination, however, is neither transparent nor well articulated. In delegating his authority to the Immigration and Naturalization Service (INS), the Attorney General made no effort to clarify the statute's "discretionary" residue. ${ }^{188}$ The INS has taken only very modest steps in that direction. Its published regulations under section 245 of the Immigration and Nationality Act $^{157}$ provide no extra-statutory criteria for exercising discretion. ${ }^{158}$ The Service's Operations Instructions merely state a "policy that the application should not be denied as a matter of discretion when substantial equities exist."159 The published decisions of the INS District Directors and the Board of Immigration Appeals (BIA) yield only a list of undefined and unweighted "adverse factors" (e.g., preconceived intent to seek permanent residence at the time of entry, misrepresentations made in the application, petty criminal conduct, illegal employment) and "equities" (e.g., bona fide marriage, substantial difficulties in resettling in or returning to one's native land, candor in dealing with the Service)..$^{160}$

The Service has frequently been criticized for the opacity of these standards. Professor Abraham Sofaer, for example, presented compelling statistical and anecdotal evidence of inconsistencies in the Service's exercise of discretionary authority. ${ }^{101}$ Discretionary denials, he observed, were considerably more susceptible to political intervention and administrative re-

154. Immigration and Nationality Act of 1952, ch. 477, § 245(a), 66 Stat. 163, 217 (current version at 8 U.S.C. $\S 1255($ a) (1976)).

155. 8 C.F.R. $\S 245.1(\mathrm{~g})(1981)$.

156. Sep id. § 2.1 .

157. Immigration and Nationality Act of 1952, ch. 477, $\S 245,66$ Stat. 162, 217 (current version at 8 U.S.C. $\S 1255$ (1976)).

158. 8 C.F.R. \& 245 (1981).

159. INS Operations Instructions $\S 245.5 \mathrm{~d}(5)$, reprinted in 4 G. GORDON \& H. ROSENFIEID, Immigration LAW AND Procedure 23-532 (1983). For assistance in determining whether "substantial equities" exist, the District Director is referred to another discretionary determination ("voluntary departure"), the published standards for which are equally opaque. See id. $\$ 242.10$, reprinted in 4 C. Gordon \& H. Rosenfield, supta, at 23-488.

160. See 2 C. GoRdon \& H. RosenfIELd, supra note 159, § 7.7d, at 790-95; Orlow, Adjustinent of Stalus of Lawful Permanent Resident, in Tenth ANNual Immigration and NaturalizaTION INSTrTUTE 151, 156-68 (A. Fragomen, Jr. ed. 1979).

161. Sofaer, supra note 153, at 365-93. 
versal than denials based on the more explicit statutory criteria. ${ }^{162}$ While most courts have upheld section 245 's discretionary power, ${ }^{103}$ a few judges have voiced concern about its breadth. Dissenting in Ameeriar v. INS, Judge Freedman characterized the Service's exercise of discretion as "an utterly unguided and unpredictable undertaking. Only the inevitable necessity of disposing of the case is specified, like a result without a cause. What is the desired goal and what guides should channel the course to it receive no recognition."16s

In 1979, the Service proposed a rule establishing standards for changing the status of aliens. ${ }^{168}$ The stated purpose of the rule was "to assure that all applicants and petitioners receive fair and equal treatment before the Service."167 The rule listed six adverse and five favorable factors, required adjustment in the absence of adverse factors, and stated a strong presumption against adjusting the status of any alien who had evaded the normal immigration process. ${ }^{168}$

While one might be tempted to dismiss these proposed rules as a mere codification of existing practice, they make more visible and mandatory what had hitherto been largely implicit. Even this modest degree of policy clarification was too much for the INS. In a terse order issued on January 21, 1981, the INS withdrew the proposed rule, stating:

[I]t is impossible to foresee and enumerate all the favorable or adverse factors which may be relevant and should be considered in the exercise of administrative discretion. Listing some factors, even with the caveat that such list is not all inclusive, poses a danger that use of guidelines may become so rigid as to amount to an abuse of discretion. ${ }^{168}$

At least the Service is consistent: its explanations are no more transparent than its rules. In order to fathom the rejection of the proposed rule, we must look behind the official explanation. Several INS district officials feared increased litigation. One particularly colorful comment predicted:

162. Id. at 385-93.

163. See, e.g., Faddah v. INS, 580 F.2d 132, 133 (5th Cir. 1978) (Finding that obtaining temporary visas by aliens intending to remain permanently is sufficient to support discretionary refusal to adjust status of aliens under $\S 245$ ); Ameeriar v. INS, 438 F.2d 1028, 1032 (3d Cir. 1971) (no abuse of discretion where alien was denied permanent resident status for bypassing normal procedures and entering country on visitor's visa with intent to remain).

164. 438 F.2d 1028 (3d Cir. 1971).

165. Id. at 1042 .

166. 44 Fed. Reg. 36,187, 36,191 (1979) (proposing 8 C.F.R. \$ 245.8). The rules also proposed standards for the exercise of several other discretionary functions.

167. Id. at 36,187 .

168. Id. at 36,191 .

169. 46 Fed. Reg. 9119 (1981). 
[T]he proposals embodied in this draft would subject the Service to a constant barrage of spurious appeal [sic] by Immigration attorneys on the basis of the semantics proposed to be injected into the regulations. They subvert Government to the vagaries of attorney dilatory tactics and would appear to tie our hands completely in the cobwebs of endless liturgical [sic] dialogue.

It is hard to take such an assertion seriously. If anything, transaction costs cut in the opposite direction. The sheer volume of status-adjustment cases is staggering. ${ }^{171}$ Moreover, most individual applicants have a sufficient interest in the outcome to expend considerable effort in the process. ${ }^{172}$ The Sofaer study showed that the Service eventually reversed over ninety percent of the initial denials appealed. ${ }^{173}$ Professor Sofaer thus regarded the savings in transaction costs from clearer rules as substantial. ${ }^{174}$

Greater clarity would, of course, entail additional $e x$ ante rulemaking costs. But that investment would undoubtedly be repaid by the reduced explanatory burden on individual adjudicators. The INS Operations Instructions require that a discretionary denial not governed by applicable precedent be accompanied by a "full discussion of the favorable and unfavorable factors" considered. ${ }^{175}$ Clearer rules could facilitate the search for applicable precedent and shrink the residual category of decisions requiring elaborate ad hoc justification.

Another current form of ex post rulemaking by the Service is the selection of precedents for publication. The Service publishes only about a hundred of the thousands of status-adjustment decisions made each year by its district directors. ${ }^{178}$ The very act of selection constitutes a form of rulemaking that could be displaced by issuing clearer $e x$ ante guidelines.

Transparent rules could achieve additional savings in transaction costs by facilitating internal quality control. Decisionmaking in statusadjustment cases is unavoidably decentralized. In most cases, ${ }^{177}$ initial de-

170. Memorandum from [name and position deleted], INS, to Lionel J. Castillo, Commissioner, INS (Sept. 12, 1978), at 1.

171. In fiscal year 1977, INS received 90,450 applications and granted 54,523. 1977 INS ANNUAL REPORT 8 (1977). In fiscal year 1978, the number of status adjustments granted rose to 101,397. 1978 INS ANNUAt. REPORT 8 (1978).

172. It is true that an alien whose application is denied for discretionary reasons can still apply for an immigrant visa at the American Consulate in his native land. But this option may entail considerable costs, including round trip transportation for the alien and his family, the delay, the risk of erroneous denial by the Consul, and in some cases exposure to military service or imprisonment at home.

173. Sofaer, supra note 153 , at 396-97.

174. Id. at 421.

175. INS Operations Instructions $\$ 245.5 \mathrm{~d}(2)$, reprinted in $4 \mathrm{C}$. GoRDON \& H. Rosenfield, supra note 159 , at $23-531$ to -532 .

176. Interview with Paul Schmidt, Acting General Counsel, INS, in Washington, D.C. (Dec. 17, 1980) (notes on file with author).

177. Nonimmigrant aliens may first apply for change of status at a deportation hearing. In that event, the initial determination is made by a Special Inquiry Officer ("immigration judge"). See 2 C. Gordon \& H. Rosenfield, supra note 159 , \$7.7e, at 7-98. 
cisions are rendered by "Immigration Examiners" assigned to the Service's thirty-six district offices. ${ }^{178}$ To control the work product of this farflung corps of adjudicators, the INS relies primarily on two devices. The weaker instrument is an exhortation in its Operations Instructions to decisionmakers to review the selected precedents periodically published by the agency. ${ }^{179}$ The stronger control is the system of hierarchical review. A superior district officer must review all discretionary denials and any discretionary approvals involving adverse factors. ${ }^{180}$ In fact, according to one former General Counsel, district directors personally review and issue all status adjustment decisions. ${ }^{181}$ In addition, unsuccessful applicants may request review at the district level by a motion to reopen or to reconsider, and may obtain a new evaluation of their application at a deportation hearing. ${ }^{182}$ More transparent decision rules would enable the Service to reduce its reliance on this elaborate system of quality control.

Clearer rules may also encourage greater compliance with the immigration laws. Every year thousands of illegal aliens seek residence in the United States. Ambiguous criteria for changing the status of nonimmigrant visitors may encourage would-be immigrants to evade proper immigration channels. Clear standards cannot, of course, discourage evasion if physical remoteness or cultural barriers block their communication to aliens. But aliens affected by status-adjustment standards are already sufficiently familiar with immigration procedures to obtain a non-immigrant visa, enter the United States, and apply for status adjustment. They are therefore likely to be aware of INS policy.

Measuring the potential costs of the incongruity produced by a more transparent standard is difficult. It is unclear what Congress intended by inserting a discretionary element. The statutory eligibility conditions seem to address the most obvious concerns (e.g., excluding "misfits" or preventing an evasion of quotas). One can imagine three possible reasons for further limiting access to status adjustment: (1) to prevent the circumvention of normal immigration channels; (2) to assure harmony between statusadjustment policy and our relations with foreign countries; and (3) to

178. Sofaes, supra note 153, at 357 n.25. Most examiners are non-lawyers. Sofaer, Judicial Control of Informal Discretionary Adjudication and Enforcement, 72 CoLUM. L. REv. 1293, 1299 (1972).

179. INS Operations Instructions $\S 245.5 \mathrm{~d}(1)$, reprinted in 4 G. GoRdoN \& H. ROSENFIELD, supra note 159 , at $23-531$.

180. Id. \& $245.5 \mathrm{~d}(3)$, (4), reprinted in 4 C. GoRdon \& H. Rosenfield, supra note 159, at 23532.

181. Letter from Charles Gordon, INS General Counsel, to James Orlow, Esq. (Feb. 25, 1972) at 1 .

182. See Orlow, supra note 160 , at $165-67$. Denial by an immigration judge (at the deportation stage) is appealable to the Board of Immigration Appeals and a Court of Appeals. Id. at 167. 
limit status adjustment to persons likely to contribute to society. The first of these purposes surely lends itself to a reasonably transparent rule. The second justifies at most a separate rule (or exception from the standard approach) for nationals of countries with whom our bilateral relations require a distinct policy.

The third hypothesized statutory objective provides the most plausible justification for resisting rule clarification. Assessing a person's prospective contribution to society, so the argument runs, is a holistic judgment that cannot be reduced to a formula. In the words of one INS official: "[T] diversity of human activities tends to continually generate new factors and issues which should logically affect the exercise of discretion." 183 At times, in fact, the Service seems to treat discretion as an advantage, rather than an absence of law. ${ }^{184}$ Perhaps the Service is following a notion akin to Professor Tribe's "structural due process" model ${ }^{185}$ or Professor Mashaw's "moral judgment" model. ${ }^{188}$ Central to these models is the injunction that the state must permit persons with whom it deals to participate in the articulation of the very standards to be applied to their case. Reliance on a transparent antecedent rule effectively precludes that participation.

But status adjustment fails to satisfy the prerequisites specified by Mashaw and Tribe. The change-of-status case is rarely a contest of relative "deservedness" or a determination of "culpability."187 Nor is it usually the focal point of a clash of fundamental values. ${ }^{188}$ While outcomes occasionally turn on the applicant's moral character, ${ }^{189}$ most of the reasons for discretionary grant or denial could be subjected to greater anterior specification without offending an applicant's humanity.

\section{Administrative Failure and Suboptimal Rule Precision}

The "precision calculus" illustrated in Section III is a normative model, not a behavioral model, of administrative rulemaking. Even if one accepts my favorable assessment of the age- 60 , bank chartering, and disability rules, one must still ask whether it is reasonable to expect policymakers systematically to investigate the consequences of their linguistic choices. Selecting the optimally precise form for a given rule would seem to re-

183. Memorandum from [name and position deleted], INS, to Lionel J. Castillo, Commissioner, INS (Sept. 15, 1978) at 1.

184. Sep 46 Fed. Reg. 9119 (1981).

185. Tribe, Structural Due Process, supra note 33.

186. Mashaw, Conflict and Compromise Anong Models of Administrative Justice, 1981 DukE

L.J. $181,188-90$.

187. Id. at $188-89$.

188. Tribe, Struclural Due Process, supra note 33, at 310-14.

189. See Matter of Francois, 10 I. \& N. Dec. 168 (1963). 
quire qualities beyond the reach of many administrators: a selfless concern for the public good, consistent goals, comprehensive vision, and accurate foresight. Real policymakers, by contrast, are ordinary mortals burdened with incomplete knowledge, imperfect vision, and selfish desires. Governmental rulemaking is plagued with "administrative failures" as numerous and stubborn as the "market failures" it theoretically seeks to correct. ${ }^{100}$

These characteristics may prevent the attainment of perfect rationality, but they need not foreclose a tolerable approximation, or "bounded rationality." does not optimize, he "satisfices." marginal deviations from the status quo against a slowly shifting threshold of acceptable performance. ${ }^{193}$ To borrow a metaphor from the "cybernetic" theorists, decisionmakers adopt thermostat mechanisms to test policies against an uncertain and changing environment. ${ }^{104}$ These adaptive responses to imperfect information do not prevent errors, but they do promise that errors will be corrected. ${ }^{195}$ Where these processes work effectively, we would expect even poorly drafted administrative rules to evolve toward the optimally precise formulation.

\section{A. Communication of Social Costs and Benefits}

This theory of error correction rests on two crucial assumptions: (1) that the social costs of excessively incongruent, inaccessible, or opaque rules will be effectively communicated to rulemakers; and (2) that rulemakers will respond to those costs. The first assumption incorporates the plausible premise that those with the most to lose (gain) from the promulgation of a particular rule will invest the most in efforts to defeat (enact) it. ${ }^{198}$ Thus, in the pilot retirement example, if aging pilots stand to lose more (in reduced income) from adoption of an "age-60" rule than younger pilots stand to gain (from more rapid advancement), one would

190. See Wolf, A Theory of Nonmarket Failure: A Framework for Implementation Analysis, $22 \mathrm{~J}$. L. \& Econ. 107, 107 (1979); see also O. Williamson, Markets and Hierarchies 20-40 (1975) (speaking of "organizational failures").

191. See March, Bounded Rationality, Ambiguity and the Engineering of Choice, 9 BeLL J. ECON. 587, 590-91 (1978).

192. H. Simon, Administrative Behayior 79 (3d ed. 1976); H. Simon, Models of Man 198 (1957).

193. See Diver, Policymaking Paradigms in Administrative Law, 95 Harv. L. Rev. 393, 399-400 (1981).

194. See W. Ashby, An Introduction to Cybernetics 24-41 (1956); J. Steinbruner, The Cybernetic Theory of Decision 51 (1974).

195. See D. Braybrooke \& C. Lindblom, A Strategy of Decision 71-77 (1963); Lindblom, The Science of "Muddling Through," 19 PuB. AD. REv. 79 (1959).

196. This is the premise of various theories of democracy, including pluralism, see R. DAHL, A Preface to Democratic Theory 134-35 (1956), and "economic theories," see, e.g., Posner, Theo- 
expect an organization representing the pilots to lobby against its adoption. ${ }^{197}$

One cannot, however, logically equate the intensity of the response to a policy decision with the magnitude of the costs and benefits generated by the decision. The cost of sending signals of equivalent intensity may not be the same for each of the interests affected. The most vociferous lobby need not have the highest stake in the outcome; it may simply have the lowest organization costs. ${ }^{198}$

The FAA's decision to adopt the age- 60 rule, for example, was greeted by intense criticism from the pilots' association and silence from the flying public. Yet the FAA should not necessarily have relaxed the rule. The net safety benefits to the public from retaining the rule might have greater value than the pilots' lost income. Yet the cost of organizing the public to lobby on behalf of the rule is much greater than the cost of organizing pilots to lobby for its relaxation, ${ }^{109}$ and pilots can communicate their views far more efficiently than airline passengers.

Of course, reality is not as clear-cut as my example. Other wellorganized factions, such as airlines and enforcement officials, may efficiently champion interests neglected by the pilots or shared by the traveling public. But the example does make the point that widely dispersed costs or benefits are less effectively represented in policymaking than concentrated costs or benefits. ${ }^{200}$ Thus we would expect error-correction to favor interests championed by enforcers and regulated firms and to undervalue interests of unorganized beneficiaries of government programs.

The effect of disparity in organization costs on the precision of particular rules is not immediately obvious. Large, unorganized groups have no intrinsic preference for transparent rules. Beneficiaries of regulatory programs, for example, are as likely to object to the over- or underinclusiveness of bright-line rules as to the evasion and misapplication of opaque rules. On occasion, however, the interests of regulated producers will diverge sufficiently from those of consumers to affect the precision of rules. Incumbent licensees, for instance, may have a powerful interest in maintaining especially vague or complex licensing standards as a barrier

\footnotetext{
ries of Economic Regulation, 5 BELL J. EcoN. 335, 344-50 (1974); Stigler, The Theory of Economic Regulation, 2 BeLL J. Econ. 3, 10-13 (1971).

197. In fact, the Air Line Pilots Association abandoned its longstanding opposition to the age-60 rule in 1980, citing its success at adjusting pilots' salaries and pensions to the age 60 retirement date. NIA REPORT, supra note 29, app. C, at C-39 to -40 .

198. See M. Olson, The Logic of Collective Action 46-47 (1965).

199. Pilots are fewer in number than airline passengers, their individual stakes in the decision are much greater, and they have already been organized for other purposes. In addition, pilots have access to the policymaking process-the right to a hearing in individual decertification actions-denied to the general public.

200. R. Noll, Reforming Regulation 39-42 (1970); W. Riker, The Theory of Polttical Conlitions (1962).
} 
to entry by competitors. ${ }^{201}$ The interest of consumers, by contrast, might be better served by clearer, more accessible standards that reduce the transaction costs of obtaining licenses. If the incumbents can organize and lobby the rulemaker more cheaply than consumers or potential entrants, the signals received by the rulemaker will be biased in favor of a Model II formulation.

Television station licensing provides a classic illustration. The standards employed by the Federal Communications Commission (FCC) for broadcast licenses have long been regarded as a model of administrative opacity. ${ }^{202}$ In thirty years of television licensing, these standards have stubbornly resisted significant clarification. ${ }^{203}$ It seems eminently plausible that this resiliency reflects an imbalance between the power of incumbent broadcasters and that of viewers and potential entrants. Because major market television franchises have enormous value ${ }^{204}$ and because new entry into that market usually displaces an existing licensee, incumbents wish to maintain high barriers to entry. Both the enormous cost of contested renewal proceedings ${ }^{205}$ and the infrequency of challenges to incumbents ${ }^{208}$ indicate that the incumbents have established such barriers by preserving the Commission's opaque renewal standards. Moreover, the affiliation of many television licensees with one of the three major networks ${ }^{207}$ decreases their organizational costs far below those of viewers or potential entrants. Consequently, neither the networks' opposition to more transparent entry criteria, ${ }^{208}$ nor the acquiescence of the networks' opponents should surprise us.

Recipients of public assistance programs, by contrast, may have a

201. On the use of regulation to create barriers to entry in general, see B. OWEN \& R. BRAEUtigam, The Regulation Game 2-9 (1978).

202. See, e.g., Anthony, Towards Simplicity and Rationality in Comparative Broadcast Licensing Proceedings, 24 Stan. L. Rev. 1, 39 (1971); Geller, The Comparatize Reneual Process in Television: Problems and Suggested Solutions, 61 VA. L. REv. 471, 500-03 (1975); Schwartz, Comparative Television and the Chancellor's Foot, 47 GEo. L.J. 655, 678-89 (1959).

203. The FCC has launched several abortive efforts to clarify its policies. See, e.g., Policy Statement Concerning Comparative Hearings Involving Regular Renewal Applicants, 22 F.C.C.2d 424 (1970), struck down in Citizens Communication Center v. FCC, 447 F.2d 1201 (D.C. Cir. 1971); Notice of Inquiry, In the Matter of Formulation of Policies Relating to the Broadcast Renewal Applicant, Stemming from the Comparative Hearing Process, 27 F.C.C.2d 580 (1971), terminated wilhout action, Report and Order, 66 F.C.C.2d 419 (1977), aff'd sub nom. National Black Media Coalition v. FCC, 589 F.2d 578 (D.C. Cir. 1978).

204. See Gass, RKO: A Special Kind of Lottery, 9 Media L. Notes 2, 3 (No. 4, 1982).

205. See Gitizens Communications Center v. FCC, 447 F.2d 1201, 1205 n.7 (D.C. Cir. 1971) (citing 1969 figure of $\$ 250,000$ to prepare an application for major-market television license).

206. From 1961 through 1978, there were 17 comparative television hearings. Central Florida Enters. Inc. v. FCC, 598 F.2d 37, 61 (D.C. Cir. 1978).

207. R. Cass, Revolution in the Wastel.and 8-12 (1981).

208. See In the Matter of Policies Relating to the Broadcast Renewal Applicant, Stemming from the Comparative Hearing Process, FCC Broadcast Docket No. 81-742, in response to Notice of Inquiry, 88 F.C.C.2d 21 (1981) (Comments of CBS, NBC, and ABC). 
stronger voice in policymaking than beneficiaries of regulatory programs. The process of individualized application, eligibility review, and termination theoretically gives recipients more direct access to policymakers than regulatory beneficiaries possess. If the stakes in individual cases frequently justify the expense of litigation and appeal, ${ }^{200}$ recipients' interests slighted at the rulemaking stage will be asserted in the adjudication of claims. Repeated efforts by individual claimants to circumvent bright-line rules will alert policymakers to their incongruity costs, just as repeated efforts to exploit ambiguities in open-textured standards will dramatize the transaction and misapplication costs.

One cannot, however, always count on beneficiary self-help to cleanse impurities in the formulation of public assistance eligibility standards. Beneficiaries, as individuals, may lack the necessary knowledge, access, or incentive. Disappointed applicants for scarce public housing units, for example, may be too demoralized to demand clarification of vague selection standards. ${ }^{210}$ Native Americans ${ }^{211}$ or aliens ${ }^{212}$ may be handicapped by cultural or linguistic barriers from effectively counteracting either the patronizing opacity or insensitive rigidity of their would-be bureaucratic benefactors.

\section{B. Divergence of Public and Private Interests}

The receipt of accurate signals about social costs and benefits is a necessary, but not sufficient, condition for optimal precision of rules. As mentioned earlier, a second condition is that the rulemaker be responsive to those signals. He must act to maximize social benefit or minimize social cost.

In today's intellectual climate that assumption may seem quaintly heroic. Most contemporary students of administrative behavior reject an earlier generation's faith in the public-spiritedness of governmental officials as hopelessly naive. ${ }^{218}$ The revisionists claim that administrators pursue strictly personal objectives like wealth, power, and fame. ${ }^{214}$ Rather than

209. Jerry Mashaw estimates the average DI claim to be worth $\$ 30,000$ to the claimant. J. Mashaw, supra note 117 , at 81 . The number of hearings demanded exceeded 300,000 in 1982 . Staff of Senate Comm. ON Finance, supra note 129 , at 70.

210. See, e.g., Holmes v. New York City Hous. Auth., 398 F.2d 262 (2d Cir. 1968).

211. See Morton v. Ruiz, 415 U.S. 199 (1974).

212. See Asimakopoulos v. INS, 445 F.2d 1362 (9th Gir. 1971).

213. See Posner, supra note 196, at 336-41. Some recent accounts of airline deregulation rely on "public interest" explanations for administrative actions in support of deregulation. See S. BREYER, Regulation and Its Reform 317 (1982); Levine, Revisionism Revised? Airline Deregulation and the Public Interest, 44 Law \& Contemp. ProBs. 179, 182 (Winter 1981).

214. W. Niskanen, Bureaucracy and Representative Government 36-42 (1971); Niskanen, The Peculiar Economics of Bureauctacy, 58 AM. ECON. Rev. PAPERS \& Procs. 293, 296-98 (1968). For a critique of Niskanen's assumptions, see Breton \& Wintrobe, The Equilibrium Size of a Budgel-Maximizing Bureau: A Note on Niskanen's Theory of Bureaucracy, 83 J. Pol. EcoN. 195 (1975). 
seeking to maximize social benefit, administrators will seek to maximize "budgets,"215 "votes,"216 or "power."217 Of course, they may also enjoy promoting "the public good."218 But actions motivated by a mix of selfish desires and idiosyncratic notions of social welfare will only incidentally correspond with the social optimum.

This view invites us to think of administrative policymakers as profitmaximizing entrepreneurs who manufacture standards. As such, the agency will select that mix of transparency, congruity, and complexity ${ }^{218}$ that maximizes its net income. Like other profit-maximizing producers, it will consider only internal costs and benefits.

Using this analysis to predict the precision in particular standards requires us to separate the various costs and benefits enumerated earlier ${ }^{230}$ into "internal" and "external" categories. The proper assignment of costs and benefits depends, of course, on the rulemaker's utility function. What is "external" to one rulemaker may be "internal" to another. A regulator seeking to maximize "votes," broader segment of the public than a regulator seeking only to maximize his own future income. ${ }^{222}$ Let us initially adopt the most restrictive assumption-that "internal" effects are only those that have a direct impact on the rulemaker's budget. In the next section we will examine the implications of relaxing that assumption. ${ }^{223}$

A policymaker concerned only with the direct fiscal impact of his actions would choose a rule that minimizes the sum of his rulemaking and enforcement costs. He would ignore its adverse consequences for private transaction costs, noncompliance, or incongruent behavior. Rules promulgated under these conditions would frequently deviate from the optimal amount of precision.

To illustrate this point, let us return to our earlier distinction between external and internal rules. ${ }^{224}$ The "externalities" hypothesis predicts that

215. Peltzman, Tourard a More General Theory of Regulation, 19 J. L. \& Econ. 211 (1976).

216. See Wilson, The Dead Hand of Regulation, 25 PUB. INTEREST 39 (Fall 1971); Wilson, The Rise of the Bureaucratic State, 41 PuB. InTEREst 77 (Fall 1975).

217. See Hilton, The Basic Beharior of Regulatory Commissions, 62 Am. Econ. Rev. Papers \& Proc. 47 (1972); Manne, Indizidual Constraints and Incentives in Government Regulation of Business, in INTERACTION OF ECONOMICS AND LaW 23 (B. Siegan ed. 1977).

218. See Eckert, On the Incentives of Regulators: The Case of Taxicabs, 14 PUB. CHoice 83, 85-88 (Spring 1973).

219. Cf. Magat \& Estomin, The Behatior of Regulatory Agencies, in AtTAcking Regulatory Problems, supra note 43, at 101 ("quality" of regulations includes "clarity of interpretation" and "ease of enforcement").

220. See supra pp. 73-74.

221. See Peltzman, supra note 215, at 211-14.

222. See Eckert, The Life Cycle of Regulatory Commissioners, 24 J.L \& Econ. 113 (1980).

223. See infra pp. 105-06.

224. See supra pp. 76-77. 
external rules will generally deviate farther from the social optimum than internal rules. An agency internalizes most of the costs and benefits associated with the precision of internal standards. An incongruent rule for assigning staff, for example, misallocates agency resources. Similarly, the unnecessary transaction costs from insufficiently transparent internal rules are borne by the agency. If an excessively vague prosecutorial guideline repeatedly forces agency prosecutors to seek interpretations from supervisors, the agency pays in lower staff productivity. Conversely, if clear staff instructions enable the agency to discipline uncooperative staff without protracted grievance hearings, the agency benefits.

A larger share of the burden inflicted by suboptimally precise external rules, by contrast, falls on persons outside the agency. Over-inclusive occupational safety standards, for example, burden employers, while underinclusive standards permit excessive injury to workers. An agency less responsive to these external costs than to its internal costs of applying rules may favor rigid, bright-line formulations over more flexible alternatives. This may help to explain the frequently observed tendency of health, safety, and environmental regulators to adopt highly specific, inflexible standards. ${ }^{225}$

Similarly, the confusion and evasion generated by regulatory vagueness may burden the regulated or benefitted public far more than the regulator. Our broadcast licensing example of the previous section provides an illustration. ${ }^{228}$ As I suggested there, vague licensing standards discourage challenges to incumbents by driving up the cost and increasing the uncertainty of comparative licensing proceedings. Yet the burden of this adverse consequence falls primarily on the viewing public and potential entrants. Those consequences of the strategy that the rulemaker bears are lower rulemaking costs and fewer hearings. From the perspective of the rulemaker's narrowly defined fiscal self-interest, the tradeoff is decidedly favorable.

To some rulemakers, rule enforcement costs are external. The purest example is a legislative body, but most administrative agencies rely to some extent on the courts, other agencies, and the public to enforce their rules. The more extreme the separation, the more appealing Model II formulations are likely to appear. The rulemaker captures the benefit of Model II rules (low initial rulemaking investment) while exporting their costs (high enforcement costs) to someone else. This analysis helps to explain why legislatures customarily use open-ended language to embody their substantive commands. ${ }^{227}$

225. SPe E. BARDACH \& R. KAGAN, supta note 4.

226. See supra pp. 100-01.

227. See Posner, Economics, Politics, and the Reading of Statutes and the Constitution, $49 \mathrm{U}$. 
The costs and benefits associated with competing formulations also have a temporal dimension. Some options, like Model III, involve a heavy initial rulemaking effort while others, such as Model II, necessitate substantial future rulemaking. Rational decisionmakers frequently encounter problems of intertemporal comparisons, of course, and routinely cope with them by discounting. By applying a suitable discount rate, the analyst converts streams of costs and benefits into present values and simply selects that option having the greatest present value. ${ }^{228}$ The same method should be used to select the optimally precise formulation of a standard.

The self-interested policymaker, however, may have an internal discount rate different from the optimal social discount rate. Whereas the social discount rate should reflect the opportunity cost of capital generally prevailing in the society, ${ }^{229}$ an administrator's individual discount rate reflects the opportunity cost of personal capital (time and effort) invested in the enterprise. ${ }^{230}$ Most political appointees, for example, have a short tenure in office and are therefore likely to assign a high opportunity cost to the investment of their time. ${ }^{231}$ Thus their discount rate will greatly exceed the social discount rate.

Socially suboptimal time horizons are a universal problem in a political system such as ours, and thus one might expect all administrative policy to be suboptimally precise. But in many agencies, the nearsightedness of political appointees is powerfully counterbalanced by strongly entrenched career bureaucrats. ${ }^{232}$ In general, older agencies will exhibit this characteristic while newer agencies are more likely to be dominated by shorttermers. ${ }^{233}$ The head of a new agency may want to show immediate results. This desire creates a strong pressure for regulatory formulae that can be enacted quickly and enforced mechanically, although a more flexible approach might achieve a better balance of social values. Shortly after its creation, for example, the Occupational Safety and Health Administration uncritically adopted thousands of detailed standards, originally developed as voluntary guidelines by private industry groups, as mandatory occupational safety standards. Only much later did OSHA begin to wrestle with the glaring incongruities produced by this strategy. ${ }^{234}$

Ghi. L. Rev. 263, 288-90 (1982); Stewart, The Reformation of American Administrative Law, 88

HARv. L. REv. 1669, 1695-96 (1975).

228. See E. Stokey \& R. Zeckhauser, A Primer for Policy Analysis 159-76 (1978).

229. See Baumol, On the Social Rate of Discount, 58 AM. Econ. Rev. 788 (1968); Marglin, The Social Rate of Discount and the Optimal Rate of Inviestment, 77 Q.J. ECON. 95 (1963).

230. See W. NiskANEN, supra note 214 , at 114-23 (bureaucrat's personal discount rate a function of expected tenure in office).

231. See Eckert, supra note 222; Hilton, supra note 217.

232. Sep M. Derthick, Policymaking for Social Security (1979).

233. M. Bernstein, Regulating Business by Independent Commission 74-95 (1955).

234. See Zeckhauser \& Nichols, The Occupational Safely and Health Administration-An Over- 


\section{Internalization of Social Costs and Benefits}

The classification of costs and benefits on which the previous argument rests is, of course, grossly oversimplified. Not even the most self-serving bureaucrats ignore the costs they inflict or the burdens they impose on persons outside their agencies. Virtually every objective commonly assumed to motivate administrators-future income, reputation, power -depends on a larger political process. ${ }^{295}$ That political process, operating through the mechanisms of authorization, appropriation, appointment, and oversight, transforms private benefits and costs into administrative resources or burdens. ${ }^{236}$ Airline pilots, for example, have repeatedly petitioned Congress to pressure the FAA to change its retirement rule. ${ }^{237}$ While successful to date, the FAA's defense against these attacks cannot have been costless to the agency.

If the political process faithfully converted social costs and benefits into administrative costs and benefits, we would not be concerned about externalities. While pursuing private gain, administrators would accomplish social good. But, of course, the process does not always work that way. Various features of our electoral process-such as the equal weighting of votes, ${ }^{238}$ the two-party system, ${ }^{239}$ and the districting of most legislatures $^{240}$-distort the communication of private preferences to the political branches. ${ }^{241}$ Other imperfections, such as the cost of effectively monitoring and controlling bureaus, ${ }^{242}$ further distort the communication of elected officials' preferences to administrative agencies.

At a minimum, therefore, one would expect external effects to lose in-

virw, in Senate Comm. on Gov'tal Affatrs, 95th Cong., 2d Sess., Study on Federal Regulation, App. to Vol. VI: Framework for Regulation 169, $200-01$ (Comm. Print 1978).

235. See, e.g., R. ARnold, Congress and the Bureaucracy: A Theory of Influence (1979); L. DOdD \& R. SchotT, Congress and the Administrative State (1979).

236. For illustrations, see W. CARY, PoltTics and tHE REgulatory Agencies (1967); THE Federal Trade Commission since 1970: Economic Regulation and Bureaucratic BehavIOR (K. Clarkson \& T. Muris eds. 1981); Parnell, Congressional Interference in Agency Enforcement: The IRS Experience, 89 YALE L.J. 1360 (1980).

237. See To Eliminate Age Limitations Presently Imposed on Certain Pilots of Aircraft: Hearings Before the Subcomm. on Aviation of the House Comm. on Public Works and Transp., 96th Cong., 1st Sess. 160-64 (testimony of Pilots' Rights Association Panel), 367-69 (1974) (submission of John Young, legislative vice president, Pilots' Rights Association).

238. See, e.g., W. Riker, Democracy in the United States 61 (2d ed. 1965). Inability to weigh votes by relative intensity of voter preferences is one of the conditions that produces the problem of cyclical majorities. See A. Mackay, Arrow's Theorem: The Paradox of Social Choice 26-27, 42-48 (1980).

239. See A. Downs, An Economic Theory of Democracy 136 (1957) (noting tendency of candidates in a two-party system to converge on the midpoint of the voter frequency distribution).

240. See Weingast, Shepsle \& Johnsen, The Political Economy of Benefits and Costs: A Neoclassical Approach to Distribution Politics, 89 J. PoL. EcoN. 642 (1981).

241. For an extreme view, see E. Nordlinger, ON the Autonomy of the Democratic STATE (1981).

242. See J. Sundquist, The Decline and Resurgence of Congress 318-24 (1981); W. NisKANEN, supra note 214, at 24-35. 
tensity in the process of political conversion. Consequently, agencies will tend to value the direct effects (on transaction costs) of their rulemaking decisions more than their indirect effects (on compliance rate and incongruity effects). To that extent, at least, the predictions advanced in the preceding section should hold true.

Political conversion often obscures the magnitude of private costs and benefits. Generally, one would expect difficulty of estimation to increase with the intensity of conflict in the political arena. The more intense the conflict, the more confused and unintelligible will be the signals received by the administrative policymaker. Estimation of the political consequences of alternative strategies will become more difficult, and the perceived political costs of selecting the wrong alternatives will rise. Faced with this dilemma, the risk-averse policymaker will tend to favor Model II formulations. Transparent rules tend to spotlight a value choice. Opponents of that choice will attack the agency's action, forcing the agency to expend its own resources for defense. Rules having low transparency thus become more attractive, since they conceal value choices.

Beyond these general observations, predictions about the effect of political distortions are difficult. Once again, public choice theory provides some guidance. ${ }^{243}$ In the distribution of political influence in the larger governmental arena-as at the administrative level-organizational costs are a crucial factor: groups with lower organizational costs will outbid those with higher costs. To the extent that the resulting distribution of administrative costs and benefits misrepresents the distribution of social costs and benefits, rules made by self-serving rulemakers will deviate from the optimally precise form.

\section{Conclusion: Administrative Rule Precision from the Judicial Perspective}

We began this journey at the courthouse, and it is time to return. Rule precision has importance not simply to administrative policymakers and their critics but to the courts as well. As the case studies and anecdotes illustrate, courts are repeatedly drawn into controversies about the appropriate precision of administrative rules as they review the legality of actions predicated upon them. What they need to discharge that function is neither philosophizing nor modelmaking, but hardheaded guidelines for adjudicating disputes between the government and the public. When is a rule so opaque that its application denies a person "due process of law"?244 When is it an "abuse of discretion" to ground actions on an

243. See supra pp. 99-101.

244. See, e.g., White v. Roughton, 530 F.2d 750 (7th Cir. 1976) (use of unwritten personal stan- 
accretion of ad hoc rationales rather than on a more comprehensive directive?245 When does the application of a rule become so mechanistic that it denies an individualized hearing guaranteed by statute?246 At what point does its application to borderline cases become arbitrary and capricious ${ }^{\mathbf{2 4 7}}$ or deny equal protection of the law?248

To a large degree, answers to these questions depend on the peculiar statutory or doctrinal context in which they arise. Regulatory incongruities that impair speech ${ }^{249}$ or disadvantage suspect minorities ${ }^{250}$ will receive far less tolerance, for instance, than those that burden economic interests. ${ }^{251}$ Some statutory schemes will display greater legislative concern for individualized treatment ${ }^{252}$ or clarity of regulatory exposition ${ }^{263}$ than others.

But even after allowing for such doctrinal or statutory peculiarities, there still remains an irreducible core of legal controversy about rule precision that yields only to an indwelling jurisprudential principle of fairness or propriety. The point of this Article has been to elaborate such a principle-one based on the norm of efficiency-and to explore its application as both an evaluative criterion and predictive model. It is not by any means the only way to think about rule precision, nor perhaps always the best way. Controversies about the transparency and congruity of certain rules are perhaps best resolved by a "moral judgment,"254 "structural due process,"255 or a "libertarian"258 model. But in the messy relativistic world of most administrative policymaking, the tensions between account-

dards in determinations of general assistance eligibility violates due process); Holmes v. New York City Hous. Auth., 398 F.2d 262 (2d Cir. 1968) (due process requires that selections among applicants for public housing be made in accordance with "ascertainable standards").

245. See, e.g., Bahat v. Sureck, 637 F.2d 1315, 1317 (9th Cir. 1981) (INS adjudication found inconsistent with agency regulations); Ruangswang v. INS, 591 F.2d 39, 46 (9th Cir. 1978) (agency cannot create new standard and apply it in context of adjudicatory process).

246. See Heckler v. Campbell, 103 S. Ct. 1952 (1983).

247. See WAIT Radio v. FCC, 418 F.2d 1153, 1157 (D.C. Cir. 1969).

248. Sep, e.g., Ambach v. Norwick, 441 U.S. 68, 72-74, 80-81 (1979) (addressing permissible statutory classifications of aliens); Nyquist v. Mauclet, 432 U.S. 1, 7-11 (1977) (same); Sugarman v. Dougall, 413 U.S. 634, 641-44 (1973) (citizenship restriction in municipal civil service "sweeps indiscriminately").

249. Sep Broadrick v. Oklahoma, 413 U.S. 601, 611-15 (1973).

250. See, e.g., Graham v. Richardson, 403 U.S. 365, 370-73-(1971) (alienage); Loving v. Virginia, 388 U.S. 1 (1967) (race).

251. See Williamson v. Lee Optical, 348 U.S. 483 (1955); United States v. Carolene Prods., 304 U.S. 144, 153-54 (1938).

252. Spe National Petroleum Refiners Ass'n v. FTC, 482 F.2d 672, 675 (D.C. Cir. 1973), cerl. denied, 415 U.S. 951 (1974).

253. Sep Rockbridge v. Lincoln, 449 F.2d 567, 569-71 (9th Cir. 1971).

254. Mashaw, supra note 186 , at 188-90.

255. Sep Tribe, Childhood, Suspect Classification and Conclusive Presumplions: Three Linked Riddles, 39 LAW \& Contemp. Probs. 8 (Summer 1975); supra note 33.

256. F. HAyek, The Constitution of Liberty 205-14 (1960); F. HAYek, The Rond to SERFDOM 72 (1944). 
ability and responsiveness, ${ }^{267}$ accuracy and fraternity, ${ }^{258}$ and individualism and altruism ${ }^{259}$ will not often yield to resolution by deontological fiat. Courts, as much as politicians, must throw competing values on the scales and somehow total the score.

It is not an easy task, especially for courts. As Jerry Mashaw has forcefully argued in a different context, courts are ill-equipped for "social-cost accounting,"260 particularly when looking over an administrative policymaker's shoulder. Not only do courts lack the administrator's presumed investigative resources, analytic competence, and technical literacy, but they view social policy issues through the refracting prism of judicial review. Resolving competing claims about the precision of rules in the context of enforcement proceedings requires courts to extrapolate from a single known application of a rule to a universe of imagined applications. Even in a pre-enforcement challenge, the restricted, party-centered empiricism of appellate review consigns the court to deciphering that artifact of litigation known as the "administrative record."

The difficulty of the task counsels broad deference to administrators' choice of rule formulations. Not only are administrators better equipped for "social-cost accounting," but, as the case studies in Section III suggest, the political "marketplace" can often be relied upon to restrain administrative excesses. Courts, however, cannot wholly escape their editorial responsibility, precisely because the formal dimensions of a rule are so intertwined with its substantive and procedural legality. If the framework presented in this Article cautions against excessive judicial intervention, it also points the way to more productive interventions. Courts should, first of all, reserve their closest scrutiny for rules least likely to be subject to effective political discipline. As organization-cost disparities progressively skew the "reinternalization" of "external" effects, the need for judicial oversight grows. Our earlier discussion suggests that courts should be most sensitive to the plaint of the unorganized beneficiary of regulatory protection and the adversarially disadvantaged public assistance recipient.

When courts are drawn into disputes about regulatory precision, they should be sensitive to the inevitable tradeoffs among transparency, accessi-

257. See Nonet, The Legitimation of Purposive Decisions, 68 Calif. L. Rev. 263, 274-77 (1980).

258. See Michelman, Formal and Associational Aims in Procedural Due Process, in Due ProcEss, Nomos XVIII, at 126 (1977).

259. See Kennedy, supra note 15.

260. Mashaw, supra note 147, at 1435-36, 1447-49; see also Mashaw, The Supreme Court's Due Process Calculus for Administrative Adjudication in Mathews v. Eldridge: Three Factors in Search of a Theory of Value, 44 U. CHI. L. REv. 28 (1976).

261. See Auerbach, Informal Rule Making: A Proposed Relationship Betueen Administrative Procedures and Judicial Review, 72 Nw. U.L. Rev. 15 (1977); Pedersen, Formal Records and Informal Rulemaking, 85 YALE L.J. 38 (1975); Verkuil, Judicial Review of Informal Rulemaking, 60 VA. L. Rev. 185 (1974). 
bility, and congruence. They should look for evidence of the factors that drive rules toward one extreme or the other-for example, the high social costs of misspecification error associated with rules of reason, the large rule application costs and quality control problems associated with per se rules. Prohibitory rules should presumptively be more transparent than licensure rules, liability rules more transparent than remedial rules, external rules more transparent than internal rules. Incongruent outcomes should be more tolerable when they appear to cluster near the boundary than at the extremes. In many ways, of course, homilies like this misrepresent the complexity of the subject. But they serve to remind us that "social-cost accounting," for all its intimidating connotations, is really the sophisticated and sensitive application of common sense. As applied to the art of regulatory rulewriting, it is a business too important to leave entirely to the accountants. 


\section{The Yale Law Journal}

Volume 93, Number 1, November 1983

\author{
John K. Setear \\ Editor-in-Chief \\ Thomas A. Smith \\ Note $\mathcal{E}$ Topics Editor \\ Kathryn R. Abrams \\ Dean M. Hashimoto \\ Daniel C. Richman \\ Stephanie I. Splane \\ Note Editors
}

C. Cabell Chinnis, Jr. Managing Editor

Mercedes A. Laing Senior Articles Editor

Robert R. Harding

Pamela S. Karlan Eben Moglen Stefan R. Underhill Article of Book Review Editors

Senior Editors

Stephen E. Creager

Eric O. Corngold

Joseph A. Franco

Michael R. Hepworth

Bruce D. Judson

\author{
Paul G. Mahoney \\ Stephen J. Massey \\ Michael B. Rappaport \\ Jefferey M. Sellers \\ Steven J. Weingarten
}

Editors
Patrick A. Malone

Emily McKillip

Clifford L. Rechtschaffen

Business Manager: Pamela Standish Editorial Assistant: Claudia Shapiro

\section{Student Contributors to This Issue}

Pamela S. Karlan, Discriminatory Purpose and Mens Rea: The Tortured Argument of Invidious Intent

Eben Moglen, Commercial Arbitration in the Eighteenth Century: Searching for the Transformation of American Law

Stephanie I. Splane, Tort Liability of the Mentally Ill in Negligence Actions 